\title{
"UNNECESSARY, AVOIDABLE, UNFAIR, AND UNJUST": [EN]GENDERED ACCESS TO CARE IN THE PPACA ERA AND THE CASE FOR A NEW PUBLIC POLICY
}

\author{
Keegan Warren-Clem*
}

I. INTRODUCTION

II. GENDER-BASED DisPARITIES IN ACCESS TO

HEALTH CARE 123

A. Socio-Economic Access to Care: The Role of Social

Determinants of Health..................................................... 124

1. Economic Stability ……………………………...... 125

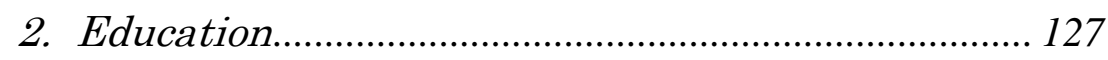

3. Social and Community Context................................ 128

4. Neighborhood and Built Environment ..................... 131

B. Financial Access to Care: The Role of Insurance .... 131

1. The Prevalence of Employer-Based Group

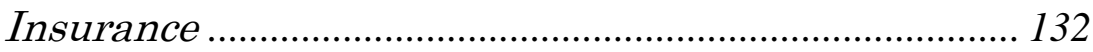

2. The Contemporary Non-Group Insurance Market 136

3. Medicaid [In]Efficacy in Facilitating Access to

Care in the PPACA Era ................................................ 149

4. Other Third-Party Payors........................................... 156

C. Reproductive Access to Care: The Role of

Competing Doctrines......................................................... 158

D. Transgendering Access to Care: The Role of the Non-Binary Gender Perspective........................................ 164

III. REMEdiating DisPaRIties In ACCESS to CARE THROUGH HEALTH AS A (NONEXISTENT) RIGHT ................... 167

A. The International Formulation of a Right to Health and Access to Care.................................................... 168

B. A Right to Health or Health Care Does Not Exist in the United States ........................................................... 171

C. Legislated Limited Rights of Access to Specific

Care in the United States.... 
D. The Melting Pot Federal Policy on Gender-Based

Health Disparities 178

IV. Shifting Public Policy in the ERa of PPACA ERA AND HEALTH-IN-ALL-POLICIES. 181

A. The Judiciary and Legislative Support for

Prioritizing Health as a Public Policy. 181

B. Access to Care Redux. 185

V. CONCLUSION 192

\begin{abstract}
Disparities in access to health care are frequently noted along racial lines, but missing from the literature is a robust discussion of the on-the-ground effects of law and policy in creating gender-based disparities outside of the abortion context. This paper seeks to fill that gap by focusing on persons similarly situated but for whom gender results in disparate access. Accepting that neither a robust right to health nor to health care exists in the United States, the paper explores how recent legislative innovations, particularly the Patient Protection and Affordable Care Act, coupled with executive initiatives and trends in the discipline of population health, suggest that a shift in public policy is occurring that could mitigate disparities for all persons if courts and state governments will follow the other federal branches' lead.
\end{abstract}

\title{
I. INTRODUCTION
}

"Can this same procedure then be done in a pregnancy, swallowing a camera and helping the doctor determine what the situation is?"1 This question was recently posed by a

* Keegan Warren-Clem, JD, LLM, was the inaugural Southern Illinois Healthcare/Southern Illinois University Medical-Legal Partnership Master of Laws Fellow. A former Equal Justice Works Fellow, she is the founding Legal Champion of Austin Medical-Legal Partnership and an Adjunct Professor at The University of Texas School of Law. Keegan is admitted to practice in Texas and is a member of the 
male state representative in Idaho in response to a physician's testimony on medical procedures she considered more dangerous than an elective abortion induced by medication. On that list was colonoscopy via camera pill, which was the procedure that prompted the Republican legislator's question. The ensuing explanation, which differentiated the digestive tract from the reproductive system, was given over the crowd's guffaws. ${ }^{2}$ The lawmaker later claimed the question had been "rhetorical."3 Whether the gentleman indeed failed to demonstrate an elementary understanding of female anatomy or whether he was merely "trying to make the point that equalizing ... procedure[s] . . . was apples and oranges," 4 he was successful at identifying at least one issue: the healthcare access needs of women of childbearing age do not necessarily come in parity with those of other sub-populations.

On the one hand, that disparate sex-based legal treatment of health issues arises as a function of the most obvious biophysical differences in men and women is of no surprise. After all, these are distinctions that invoke the most intimate of considerations. To the extent that the medical treatment in question derives from genuine sexbased biophysical variations, so, too, should the legal response vary. As a result, it would seem logical that jurisprudence on access to health care would reflect genderbased distinctions in need for care. The testimony described above could be an apt example of state intervention in the

State Bar College, an honorary society of the most highly trained lawyers in Texas. She earned her J.D. from The University of Texas and her B.A. from the University of Arkansas. Keegan thanks Jennifer Brobst for guidance and patience as this article was being researched and written.

1 Chemical Abortions: Hearing on H.B. 154 Before the H. State

Affairs Comm., IDAHO LEG. (Feb. 23, 2015), http://so.legislature.idaho.gov/MediaArchive/ShowCommitteeOrMedia.

do (statement of Rep. Vito Barbieri, Member, H. State Affairs Comm.) (63 ${ }^{\text {rd }}$ Leg., Reg. Sess.).

2 Id.

3 Kimberlee Kruesi, Lawmaker Asks if Swallowed Camera Be [sic] Used for Female Exam, Washington Times (Feb. 23, 2015, 9:16 PM), http://www.washingtontimes.com/news/2015/feb/23/lawmaker-asks-ifswallowed-camera-be-used-for-fema/?page=all [http://perma.cc/4VAA5AKA].

${ }^{4}$ Id. (quoting Idaho Rep. Vito Barbieri). 
process of access to health care by certain women-i.e., would-be mothers seeking an abortifacient pill-in the name of protecting those women.

On the other hand, the aforementioned legislature was considering restrictions on the use of telemedicine related only to accessing an otherwise lawful medical procedure. ${ }^{5}$ That is, men who sought treatment or diagnosis via the medium of telemedicine would not be similarly restricted. (Neither, of course, would women seeking other types of treatment.) Indeed, the testifying physician was arguing that the remote performance of riskier medical procedures would not be proscribed, suggesting that this legislation was targeted at restricting the ability of women to access one particular type of medical care where a provision that expressly sought to interfere with access to that care would not be constitutionally permissible. Nor was it even actually a mere attempt to institute broad protections of health: one of the bill's proponents bluntly stated that the intended effect was a circumscription on the target patient's healthcare options. ${ }^{6}$

This paper theorizes that insofar as law and policy, through such determinations as above, has traditionally created a de facto gendered system of haves and have-nots in terms of access to care, contemporary efforts to remedy disparities in access exist sufficiently to create a public policy that prioritizes access to care and health in general. The paper begins by briefly laying out broad factors that tend to influence access to care and health, noting in particular how the socio-economic environment creates foundational genderbased disparities in access to care. It then provides a broad overview of the current status of access to care from several perspectives, with a focus on new data pertinent to systemic changes to the healthcare financial structure by the Patient Protection and Affordable Care Act. The paper specifically makes note where these disparities are biophysically based

\footnotetext{
5 Physician Physical Presence and Women Protection Act, H.B. 154,

63 ${ }^{\text {rd }}$ Leg., Reg. Sess. (Idaho 2015) (enacted), http:// www.legislature.idaho.gov/legislation/2015/H0154.pdf [http://perma.cc/ $\mathrm{X} 4 \mathrm{XC}-7 \mathrm{R} 53]$.

${ }^{6}$ Kruesi, supra note 3 (quoting Republican representative Linden Bateman's statement that "[i]n my view, this may reduce the number of abortions.").
} 
on different sex-based medical needs, or whether they are the result of social constructs that may better lend themselves to legal remedy. The paper selectively employs both case law and legislative trends to explore the arc of justifications for, and interests that tend to interfere with, health care access according to the patient's gender.

Insofar that remediable disparities in access exist, the paper explores in the next section the limited rights to access to health care, along with other efforts to remedy genderbased disparities in access to care. Finally, the paper concludes by assuming that although health care perhaps cannot be understood as right-like, health is broadly regulated in ways that tend to support individual access. This is a theme that should be incorporated into judicial decisions on issues affecting health, which would tend to rectify disparate results in access to care. Here the paper imports lessons from other pertinent legal perspectives, such as public health law, in the creation of outcomes that are doctrinally consistent, equally protective, and in furtherance of systemic health goals for humans of all genders.

\section{GeNDER-BASED Disparities IN ACCess to HeAlth CARE}

What is it to have access to health care? Insofar as it may be conceptualized as the ability to receive care in support of one's health, the 1948 constitution of the World Health Organization (WHO) is instructive: there health is defined as "a state of complete physical, mental, and social well-being and not merely the absence of disease or infirmity." 7 It is a definition that has remained unchanged for nearly seventy years, ${ }^{8}$ suggesting that access to care for health has long been understood as encompassing access to both holistic

7 World Health Organization Constitution [WHO], Constitution of the World Health Organization, (signed on Jul. 22, 1946), available at http://www.who.int/governance/eb/who_constitution_en.pdf [http:// perma.cc/SUD2-U7GF].

8 WHO, WHO Definition of Health, http://www.who.int/about/ definition/en/print.html [http://perma.cc/JLZ7-GZL3] (last visited Nov. 1, 2015). See also WHO: From Small Beginnings, 9 World Health F. 29 (1988) (discussing background on the wording of the definition). 
preventative services and medical treatment targeted at specific conditions. From a gender-equity doctrinal perspective, this means that, barring a pertinent biophysical feature that inheres in one sex or the other, similarly situated men and women alike should have the same access to both wellness care and needed medical treatment. ${ }^{9}$

The evolving definition of health-related disparities accords. WHO defines disparities or inequities as those "differences in health which are not only unnecessary and avoidable but, in addition, are considered unfair and unjust."10 Nonetheless, our legal understanding of health and health care is not consistent with this proffered tenet, in part, perhaps, because access to health care is in reality a multifactorial inquiry influenced by a variety of laws and policies. In this section, this paper provides a comprehensive overview of health access before turning to law that influences access to care using, predominantly, a "life-cycle" approach rather than focusing on isolated points in time, and highlighting results that are unnecessary, avoidable, unfair, and unjust. ${ }^{11}$

\section{A. Socio-Economic Access to Care: The Role of Social Determinants of Health}

"These will be needless deaths-deaths which should shock our conscience and shame our sensibilities. How do we

9 This paper does not seek to implicate constitutional arguments regarding gender discrimination in every instance of observed gender disparity in access to health care. Nonetheless, it is not unimportant that "similarly situated" is a term of art within equal protection and many other doctrines. For an extensive treatise on the meaning and treatment of the phrase in jurisprudence, see generally Giovanna Shay, Similarly Situated, 18 GEO. MASON L. REV. 581 (2011).

10 For background on WHO's deliberation on this definition, see Margaret Whitehead, WHO, The Concepts and Principles of Equity and Health, 6 HEALTH PROMOTION INT'L 217 (1991).

11 Because health does not occur in isolation from the rest of one's life, a life-cycle approach is most appropriate in determining access to care. See generally Steven Miles, Gender and Health Insurance, 23 WM. MitCHELL L. REV. 313, 314-21 (1997) (describing work history and social programs as sources of conflicts and disadvantages by gender that are "magnified because of life cycle effects"). 
explain that the difference between life and death is a matter of dollars?"12

Nearly a half-century after the question was posed, the "how" remains a difficult question. The "why" is not: health care is expensive, and so much so that traditionally the two most widely accepted measures of access to care are the status of healthcare insurance coverage and financial barriers. ${ }^{13}$ Yet there is growing appreciation of the importance of the social and physical environment, absent individual constitutional susceptibilities, as the most influential factor on health itself. Thus mitigation or elimination of negative social determinants of health (SDOH) is a foundational mechanism for law and policy to increase access to care-or fail to assuage gender-based disparities in access.

The U.S.'s Healthy People 2020 initiative lists five key areas of SDOH: (1) economic stability; (2) education; (3) social and community context; (4) health and health care; and (5) neighborhood and built environment. ${ }^{14}$ While access to care can be considered a mere component of the fourth key area, health and health care, it would present an incomplete picture to not consider briefly how the other four key areas of SDOH underlie access to care.

\section{Economic Stability}

Because healthcare insurance acts as a proxy for access to care, a tenet explored in greater detail infra, lack of or

12 EzeKiel J. Emanuel, The Ends of Human Life: Medical Ethics IN A LIBERAL POLITY 100 (1994) (quoting Senator Vance Hartke).

13 See, e.g., Kaiser Family Found., Putting Men's Health Care DISPARITIES ON THE MAP: EXAMINING RACIAL AND ETHNIC DISPARITIES AT THE STATE LEVEL 33 (2012), available at https:// kaiserfamilyfoundation.files.wordpress.com/2013/01/8344.pdf [http:// perma.cc/9AAQ-JEE2] (listing having a regular healthcare provider as the third widely accepted measure of healthcare access).

14 Social Determinants of Health, HealthyPeOPle.Gov, http://www.healthypeople.gov/2020/topics-objectives/topic/social-

determinants-health [http://perma.cc/6Y2E-67ZL] (last visited Nov. 1, 2015) [hereinafter Healthy People 2020]. Healthy People 2020 is a federal interagency population health workgroup that seeks, inter alia, to achieve heath equity. 
insufficient coverage tends to create financial barriers to timely care. Confounding any unequal distribution of insurance between men and women are inequalities in financial resources. Limited resources amongst those of modest income decrease overall health, thereby stimulating a greater need for health care. ${ }^{15}$ Unfortunately, limited financial resources also decrease the ability to acquire that care, as does lower overall health. ${ }^{16}$ In other words, economic stability is tautologically related to both health and access to care. To the extent that access is about the ability to purchase the goods and services of health care, it is only logical that less money reduces the ability to acquire care. If access to care is understood more broadly, to include adequate transportation, childcare, and ability to miss work, then fewer resources acts as a compounding factor to the access inequity. In terms of both financial ability to purchase care and other resource-related barriers to care, women are more likely to be at disadvantage ${ }^{17}$ suggesting that their access is more significantly reduced by economic instability than that of men.

Further influencing the disparate effect of economics on access to care is that even amongst those with adequate financial resources, women earn less than men across all indicators, including where each is similarly educated, has similar experience, and is in the same occupation. ${ }^{18}$ Whether the earnings gap creates unequal access amongst higher earners in reality is improbable, particularly for relatively inexpensive health services; but, as a philosophical matter, men are privileged relative to women in experiencing

15 See George A. Kaplan, The Poor Pay More: Poverty's High Cost to Health 8 (2009) ("Most diseases are more common among the poor, and those that are not, such as breast cancer, tend to have worse outcomes for poor people.").

16 See id. at 17 ("Because they often lack health insurance benefits from work, many poor and near-poor families have inadequate access to medical care. Being poor and uninsured means having less access to preventive care, diagnostic services and treatment, and having, overall, poorer care").

17 See infra text accompanying notes 50-51.

18 See Claudia Goldin, A Grand Gender Convergence: Its Last Chapter, 104 AM. ECON. REV. 1091, 1093-1103 (2014) (presenting findings in earnings by gender over the life cycle and by occupation). 
lessened consequences of profession-based economic instability on access to care. ${ }^{19}$

Law seeks to effect economic stability for those of modest income through federal programs such as the Supplemental Nutrition Access Program; the Women, Infants, and Children program; and the Temporary Assistance to Needy Families program. Concordant with the supposition that women's access to care is disproportionately affected by economic stability, each of these programs has overwhelmingly higher enrollment by women. ${ }^{20}$ This suggests either that women's economic misfortune is more likely to be mitigated or, more probable given the low actual value provided by these programs, women are indeed suffering more from economic instability and, thus, in access to care.

\section{Education}

Educational attainment is a strong indicator of overall health, and lack thereof thus plays a unique role in defeating access to health care across both genders. ${ }^{21}$ For example,

19 See Michael Daly et al., A Social Rank Explanation of How Money Influences Health, 34 HEALTH Psychol. 222, 223 (2015) (distinguishing the material and psychosocial health effects of financial resources, and finding that each positively correlates with improved health, including through increased access).

20 Adult men are not eligible for WIC benefits, though their children may be even in the absence of the mother. See, e.g., U.S. DEP'T OF AGRIC., CHARACTERISTICS OF Supplemental Nutrition Assistance Program HOUSEHOLDS: FISCAL YEAR 2011 xvi (2012), available at http:// www.fns.usda.gov/sites/default/files/2011Characteristics.pdf [http:// perma.cc/3BUX-8SA9] ("In fiscal year 2011, . . . [a]bout 62 percent of [participating] nonelderly adults were women, as were 66 percent of elderly adults."); GENE FALK, TEMPORARY ASSISTANCE FOR NEEDY FAMILIES (TANF): SIZE AND CHARACTERISTICS OF THE CASH ASSISTANCE CASELOAD 5 (2014), available at https://www.fas.org/sgp/crs $/ \mathrm{misc} /$ R43187.pdf [http://perma.cc/GFB5-4VV4] ("In FY2011, 84.7\% of adult recipients were women.").

21 E.g., Why Does Education Matter So Much to Health?, RoBERT WoOD JOHNSON FOUND. (Mar. 2013), http://www.rwjf.org/content/dam/ farm/reports/issue_briefs/2012/rwjf403347 [http://perma.cc/7XUV-FR32] (giving an overview of studies showing that the better educated live longer, are less likely to have and die from common acute and chronic diseases, are less likely to be overweight or obese, and are less likely to engage in health-harming behaviors). 
higher education is correlated with both lower incidence of disease and lower mortality. ${ }^{22}$ But how well one does in school can inform access to care on a gendered basis because higher educational performance by women is not associated with higher pay relative to men. ${ }^{23}$

Recent shifts in the college graduation rate norms may result in increases in private healthcare insurance coverage for women and proportional decreases for men. Education positively correlates with healthcare insurance coverage for both genders, regardless of whether or not an employer provides such a plan. ${ }^{24}$ That is, individuals with at least a baccalaureate degree are more likely to be insured than those with only a high school education even when employed by a business that does not offer healthcare insurance. ${ }^{25}$ Given that women now enroll in college in significantly higher numbers than men, ${ }^{26}$ it might expected that the former will experience a growth in healthcare coverage relative to the latter.

\section{Social and Community Context}

The effects on health of the social and community environment are divided into social cohesion, civic

$22 I d$.

23 Michael T. French et al., What You Do in High School Matters: High School GPA, Educational Attainment, and Labor Market Earnings as a Young Adult, 41 EASTERn ECON. J. 370, 376-82 (2015). See also Jillian Berman, Female 'A+' Students End Up Making As Much As Male ' $C^{\prime}$ Students, Huffington Post (May 23, 2014, 7:31 AM), http://www.huffingtonpost.com/2014/05/23/gpa-income_n_5373078.html [http://perma.cc/X84S-CUSM] (providing a sex-based graph of the final results of aforementioned study of earnings relative to high school grade point average).

24 Hubert Janicki, U.S. Census Bureau, Employment-Based HEALTH INSURANCE: 2010, at 13 (2013), available at https:// www.census.gov/prod/2013pubs/p70-134.pdf [http://perma.cc/4HMF$68 \mathrm{VP}]$.

25 Id.; Goldin, supra note 18, at 1091-92.

26 See Mark Hugo Lopez \& Ana Gonzalez-Barrera, Women's College Enrollment Gains Leave Men Behind, Pew Research Center (Mar. 6, 2014), http://pewrsr.ch/1qckLFE [http://perma.cc/Z5BX-HFYT] ("By 2012 , the share of young women enrolled in college immediately after high school had increased to $71 \%$, but it remained unchanged [since 1994] for young men at $61 \% . "$.). 
participation, perceptions of discrimination and equity, and incarceration and institutionalization. ${ }^{27}$ These categories are pertinent to disparities in access to care insofar as social interaction affects a person's ability and willingness to obtain needed health care. Although generally a more social than legal concept, cultural expectations are a significant confounder that affect perception of health and health risks, and that may be formally codified or informally reinforced through legal tolerance of a practice.

For example, culturally bound illnesses-those that "the patient perceives from a sociocultural perspective," as opposed to "what the physician diagnoses from a biomedical understanding"-inform health-seeking behaviors. ${ }^{28}$ A subsequent reduction in access to care may occur because legal restrictions override the cultural instinct to seek or avoid care, or they may interfere with the availability of culturally appropriate care. That is, because culturally bound illness generally needs a culturally appropriate healthcare provider, regulation of entry into the practice of medicine can render such care difficult to find.29 Access to care necessarily suffers when healthcare providers are unavailable. Any effect on access, however, is experienced by all members of the subpopulation regardless of gender.

Dissimilarly, women have a disproportionate limitation on access to care where society tends to place them in a subordinate position. ${ }^{30}$ Often this hierarchy is reinforced by

27 Healthy People 2020, supra note 14.

28 Juan Carlos Belliard \& Johnny Ramírez-Johnson, Medical Pluralism in the Life of a Mexican Immigrant Woman, 27 HISP. J. BEHAV. SCI. 267, 269 (2005).

29 See $i d$. at 278 (describing an interviewee's rejection of the idea of going to a traditional clinic for a culturally bound illness because "doctors do not understand those diseases").

30 See, e.g., Farzaneh Roudi-Fahimi, Gender and Equity in Access to Health Care Services in the Middle East and North Africa, PoP. REFERENCE BUREAU, http://www.prb.org/Publications/Articles/2006/ GenderandEquityinAccesstoHealthCareServicesintheMiddleEastandNo rthAfrica.aspx [http://perma.cc/Z6US-JTX3] (last visited Nov. 1, 2015) (describing how a culture with a tradition of strong gender roles affects the perception of health by women); WHO, HEALTH IN ALL POLICIES TRAINING MANUAL 28 (2015) [hereinafter WHO HiAP] ("In some countries, gender can make a significant difference due to social attitudes about the value of men and women. For example, parents might be more 
discriminatory law and policy, or through informal mechanisms of intolerance, such as gender bias by providers. ${ }^{31}$ The resultant reduction in access to care can be a result of socio-legal control of women's movements and time, or simply a socially ingrained tendency to minimize, or failure to recognize, certain health issues. ${ }^{32}$ At the same time, social notions of "machismo" can lessen men's access to care by simultaneously encouraging them to engage in health-harming behaviors and also discouraging them from seeking health care. ${ }^{33}$ In both instances, the requisite health care may be otherwise available, and access is reduced merely through social construct.

Additionally, to the extent that incarceration informs the social context of health, institutionalization achieves increases in access to care for the uninsured, though certainly not in an ideal way. On the other hand, the criminal justice system can limit access to care insofar as it may restrict reproductive choices as a condition of probation or parole, which may be a penalty more frequently prescribed for men while more broadly affecting women. ${ }^{34}$

likely to take a son to get immunized than a daughter because of social customs that value men over women.").

31 David Gomez et al., Gender-Associated Differences in Access to Trauma Center Care: A Population-Based Analysis, 152 SURGERY 179, 184 (2012).

32 E.g., Roudi-Fahimi, supra note 30 (noting that reproductive health is frequently ignored by women in the Middle East and North Africa unless it interferes with childbearing).

33 See Kristen W. Springer \& Dawne M. Mouzon, "Macho Men" and Preventive Health Care: Implications for Older Men in Different Social Classes, 52 J. HEALth \& Soc. BEHAV. 212 (2011) (comparing the effects of masculinity on men across various socio-economic statuses).

34 Rachel Roth, "No New Babies?": Gender Inequality and Reproductive Control in the Criminal Justice and Prison Systems, 12 AM. U. J. GENDER SOC. POL'Y \& L. 391, 392-93 (2004) (noting that "to the small extent that appellate courts have been willing to uphold sex or fertilityrelated conditions of probation, they have done so with respect to men" but arguing that such orders "can only be carried out on the backs of women."). 


\section{Neighborhood and Built Environment}

The built environment concerns the physical space in which one lives, works, and plays. From an access to care perspective, local availability of a sufficient number and type of healthcare providers is perhaps the most significant indicator of the effect of the built environment. In general, women are less likely than men to have access to outpatient services, specialized inpatient care, and trauma centers. ${ }^{35}$ As a normative matter, however, men and women do not seek preventative health care in equal numbers, and men are less likely to receive preventative care than women. How much less likely? A 2001 study by the Centers for Disease Control and Prevention (CDC) found that "[t]he rate of visits by women for non-illness was 100 percent higher than among men, after controlling for age and removing pregnancyrelated visits." 36 A decade later, the results scarcely changed. The most recent such CDC study found a preventative care visit rate for women of 82.9 visits per one hundred persons and a rate for men of 46.8 visits per one hundred persons, a difference still approaching one hundred percent. ${ }^{37}$ Men are also significantly less likely to have a dedicated primary care physician. ${ }^{38}$ Although gender-based differences in access to care are almost certainly multifactorial, lack of physical proximity to providers, a result of the built environment, necessarily contributes. ${ }^{39}$

\section{B. Financial Access to Care: The Role of Insurance}

"In 1900, the average American spent $\$ 5$ a year on health care ( $\$ 100$ in today's money). No one had health insurance,

35 Gomez, et al., supra note 31 , at $179,181-84$.

36 KATE M. BRETT \& CATHARINE W. BuRT, UtILIZATION OF Ambulatory Medical Care by Women: United States, 1997-98, 12 (2001), available at http://www.cdc.gov/nchs/data/series/sr_13/ sr13_149.pdf [http://perma.cc/WH4S-9WRB] (emphasis added).

37 Chun-Ju HsiaO ET al., National Ambulatory Medical CaRe SURVEY: 2007 SUMMARY 4 (2010), available at http://www.cdc.gov/nchs/ data/nhsr/nhsr027.pdf [http://perma.cc/RNX8-UUQL].

38 Id. at 15.

39 Samina T. Syed et al., Traveling Towards Disease: Transportation Barriers to Health Care Access, 38 J. CMTY. HEALTH 976, 990 (2013). 
because you don't need insurance for something that costs $\$ 5$ a year." 40

In general, it might be said that in order to access any service, one must be able to pay for it. Health care in the United States is no exception, as it is currently financed and delivered, but the availability of healthcare insurance, or other health plan, begins to render individual fiscal ability to buy care as unnecessary as it was before such insurance existed. Indeed, in 2014 out-of-pocket contributions constituted only $10.9 \%$ of healthcare expenses, including copayments, deductibles, and other costs not covered by insurance. ${ }^{41}$ These statistics do not suggest that insurance always makes all care affordable, but rather to acknowledge health insurance as arguably the most important consideration in access to care, as well as a proxy for the same. ${ }^{42}$ Thus, this subsection explores the facilitation of access to health care via insurance.

\section{The Prevalence of Employer-Based Group Insurance}

The beginnings of healthcare insurance in the United States are well-documented, ${ }^{43}$ but it is worth noting that it is

40 Alex Blumberg \& Adam Davidson, Accidents of History Created U.S. Health System, NAT'L Pub. RADIO (Oct. 22, 2009, 3:28 PM ET), http://www.npr.org/templates/story/story.php?storyId=114045132 [http://perma.cc/V226-N4JA].

41 The percentage given was derived by dividing the federal government's official tally of out-of-pocket expenses $(\$ 329,819,000,000)$, defined in the text, by total expenditures $(\$ 3,031,292,000,000)$. See CTR. Medicare \& MEDiCAID SERV., U.S. DeP’T OF Health \& Human SERV., National Health Expenditures by Type of Service and Source of FUNDS, CY 1960-2014 (2015), available at http://www.cms.gov/ResearchStatistics-Data-and-Systems/Statistics-Trends-and-Reports/ NationalHealthExpendData/NationalHealthAccountsHistorical.html.

42 This statement is a common understanding. See, e.g., KAISER Family Found., Women's Health Insurance Coverage (2014) [hereinafter KFF WOMEN's HEALTH INSURANCE COVERAGE], available at http://files.kff.org/attachment/fact-sheet-womens-health-insurancecoverage [http://perma.cc/Z9D8-UXZW] ("Health insurance coverage is a critical factor in making health care affordable and accessible ....").

43 See generally Arthur Daemmrich, U.S. Healthcare Reform and the Pharmaceutical Market: Projections from Institutional History, 15 PHARMS. POL'Y \& L. 137 (2013) (giving an overview of the history of healthcare insurance in the U.S.). 
a relatively recent invention-as is the immense cost of health care. Whereas other forms of insurance date to the famous marketplace at Lloyd's in the seventeenth century, ${ }^{44}$ the first individual healthcare insurance was a limited, local plan that did not begin until the mid-nineteenth century. ${ }^{45}$ Group healthcare insurance, soon called "Blue Cross" and followed by its future partner "Blue Shield," did not commence until 1929. ${ }^{46}$ More than a decade later, healthcare insurance began to be provided widely by employers when it became a standard part of the benefits package during the Second World War. ${ }^{47}$ Notably, the need to attract women to the workforce catalyzed the availability of insurance for employees. ${ }^{48}$ The proliferation was further fed by increasingly business-friendly tax treatment of the benefit. 49

Today, however, women are less likely than men to have coverage provided by an employer, despite the fact that women work for employers offering healthcare insurance in higher proportion than men. ${ }^{50}$ This may be because womenand especially those who are mothers-are more likely than men to be employed on a part-time basis; yet fewer benefits, including healthcare insurance, are typically available for

44 See Ken Brownlee, History of Adjusting-Part 3: The Great Fire of London and the "Writing Under" Principle, ClaIMs MAG., Mar. 2014, at 60 (noting that by February 1688 "both Lloyd's Coffee House and losses covered by insurance had already become synonymous").

45 Daemmrich, supra note 43, at 138.

46 Id. at 139.

47 Id.

48 See id. at 139 (noting that wage controls discouraged higher salaries causing benefits as healthcare insurance to become more generous); Claudia Goldin, The Role of World War II in the Rise of Women's Work 3 (Nat'l Bureau of Econ. Research, Working Paper No. 3202 , 1989) (describing "a variety of mechanisms" that were used to increase the numbers of women working during World War II), available at http://www.nber.org/papers/w3203.pdf. [http://perma.cc/72PZ-GJEF].

49 See Blumberg \& Davidson, supra note 40 (noting the first changes to the Internal Revenue Code were in 1943); Daemmrich, supra note 43, at 139 (describing additional changes in 1954).

50 Hubert Janicki, Employment-Based Health Insurance: 2010, U.S. Census Bureau 6 (Feb. 2013), https://www.census.gov/ prod/2013pubs/ p70-134.pdf [http:/perma.cc/X49N-LP5L]. 
part-time work. ${ }^{51}$ Women are also more likely to be employed in lower valued jobs with fewer benefits. ${ }^{52}$ Indeed, $22 \%$ of women with private insurance receive that coverage through a spouse's employer, and 30\% are covered as the employee. ${ }^{53}$ In contrast, only $13 \%$ of men are dependent on their spouse for employer-based healthcare insurance, while $44 \%$ are provided coverage as the employee. ${ }^{54}$ In total, however, $55 \%$ of the U.S. population in 2011 had employment-based healthcare insurance. ${ }^{55}$ Amongst those without such coverage, cost is more likely to be cited as a prohibitive factor by men rather than women, but ineligibility for and denials of coverage affect similarly non-elderly adults regardless of gender. ${ }^{56}$

The Patient Protection and Affordable Care Act of $2010^{57}$ (PPACA) sought to remedy some of this disparity through the creation of the Small Business Health Options Program (SHOP) exchange.58 To participate in a health benefit exchange as a small business, the entity must employ at least one and no more than 100 employees. ${ }^{59}$ As with the individual exchanges, discussed immediately infra, states had the option to run their own SHOP exchange, to cooperate

51 See Jeffrey Wenger, The Continuing Problems with Part-Time Jobs, ECON. POL'Y InST. 1-12 (Apr. 24, 2001), http://s3.epi.org/files/page//old/issuebriefs/ib155/ib155.pdf [http://perma.cc/5KGW-6P7L] (finding that women work two-thirds of all part-time jobs, which are also the lowest paying and often lowest skilled with fewer benefits).

52 Sabrina Matoff-Stepp, Bethany Applebaum, Jennifer Pooler \& Erin Kavanagh, Women as Health Care Decision-Makers: Implications for Health Care Coverage in the United States, 25 J. HeAlth CARE PoOR \& UNDERSERVED 1507, 1509 (2014), available at http:// muse.jhu.edu/journals/journal_of_health_care_for_the_poor_and_unders erved/v025/25.4.matoff-stepp.pdf [http://perma.cc/P26X-F5RV].

53 KFF WOMEN's HEALTH InSURANCE COVERAGE, supra note 42, at 1.

54 Id.

55 Janicki, supra note 50, at 1.

56 Id. at $13-14$.

57 Patient Protection and Affordable Care Act of 2010, Pub. L. No. 111-148 [hereinafter PPACA] (codified as amended in scattered sections of 42 U.S.C.).

58 PPACA $\S 1311(\mathrm{~b})(1)(\mathrm{B})$ (codified at 42 U.S.C. $\S 18041$ (2015)).

59 PPACA $\S 1304(a)(2)$ (codified at 42 U.S.C. $§ 19024)$. For the first three years after enactment, each state was given the option of defining a "small business" to include only those employing fewer than fifty employees. PPACA § 1304(a)(3) (codified at 42 U.S.C. § 18024). 
with the federal government to create a SHOP exchange, or to have the federal government create and manage the SHOP exchange.60 Regardless, they were "designed to assist qualified employers in the State who are small employers in facilitating the enrollment of their employees in qualified health plans offered in the small group market in the State." 61

However, a November 2014 report by the Government Accountability Office found that after the first six months, SHOP enrollment in the eighteen states that created their own SHOP (instead of using the federal system) included only 76,000 individuals in plans purchased through fewer than 12,000 employers. ${ }^{62}$ The low enrollment may be attributed to delays in implementation until 2016.63 Numbers for enrollment by men versus women are not yet available. ${ }^{64}$

All of these factors together mean the employment-based healthcare insurance market favors men in creating financial access to healthcare providers and access to healthcare overall. ${ }^{65}$ Law supports this result through direct regulation of the market, including by not requiring that all employees receive employment-based healthcare coverage. To the extent that legal protections for benefits exist for full-time employees, they extend to part-time employees only in theory. 66 And as noted above, women are significantly more likely than men to work in part-time positions.

60 PPACA $§ 1311(\mathrm{~b})(1)(\mathrm{B})$ (codified at 42 U.S.C. $§ 18041$ (2015)).

61 Id.

62 U.S. Gov't Accountability OfFice, Small Business Health INSURANCE EXCHANGES: LOW INITIAL ENROLLMENT LiKELY DUE TO Multiple, Evolving FACTORs 12 (2014), available at http:// www.gao.gov/assets/670/666873.pdf [http://perma.cc/XG7B-PTGB].

63 Patient Protection and Affordable Care Act; Exchange and Insurance Market Standards for 2015 and Beyond; Final Rule, 79 Fed. Reg. 30240, 30249-50 (May 27, 2014) (codified at 45 C.F.R. § $155.705(\mathrm{~b})(2)-(3)(2015))$.

64 See generally U.S. Gov'T ACCOUNTABILITY OFFICE, supra note 62.

65 Gender Differences and the ACA, CTR. HEALTH \& ECON. tbl. 5 (Apr. 16, 2014), http://healthandeconomy.org/gender-differences-and-the-aca/ [http://perma.cc/ZDL2-JG6M].

66 Vai Io Lo, Atypical Employment: A Comparison of Japan and the United States, 17 COMP. LAB. L.J. 492, 515-16 (1996) ("[L]egal protections 


\section{The Contemporary Non-Group Insurance Market}

The private healthcare insurance schema was fundamentally altered by PPACA and done deliberately so. 67 The act's insurance exchanges, later rebranded the Health Insurance Marketplace (HIM), have the potential to provide a robust alternative to traditional employer-based insurance through both the individual HIM and the group insurance SHOP exchange. Whereas in 2013, the year before the HIM provisions took effect, equal proportions of men and women purchased insurance on their own, 68 by the end of the second enrollment period in early 2015, fewer men had purchased coverage through the HIM: fifty-four percent of enrollees were women. ${ }^{69}$ Total enrollment is expected to grow to include another ten million persons by the end of 2016,

for regular employees under federal law are theoretically applicable to nonregular employees. [But] nonregular employees ... receive inferior treatment in various aspects of employment, either because they fail to satisfy certain threshold requirements or because exemptions exist which permit employers to treat nonregular workers differently than regular workers.").

67 See, e.g., William P. Brandon \& Keith Carnes, Federal Health Insurance Reform and "Exchanges": Recent History, 25 J. HEALth CARE FOR THE POOR \& UNDERSERVED xxxii, xxxii (2014) (calling the HIMs the "major national innovation" of the legislation).

68 See Health Insurance Coverage of Women, KAISER FAMILY FOUND. 19-64 (2013), http:// kff.org/other/state-indicator/nonelderly-adultwomen/ [http://perma.cc/ 696Q-KSVX] [hereinafter KFF Coverage of Women] (showing that $8 \%$ of women nationwide were enrolled in private insurance that is not employer-sponsored in 2013); Health Insurance Coverage of Men, KAISER FAMILY FOUND. 19-64 (2013), http://kff.org/other/state-indicator/nonelderly-adult-men/ [http://perma.cc/H3QU-KRY7] [hereinafter KFF Coverage of Men] (showing that $8 \%$ of men nationwide were enrolled in private insurance that is not employer-sponsored in 2013).

69 Health Insurance Marketplaces 2015 Open Enrollment Period: March Enrollment Report, DEP'T OF HEALTH \& HuMAN SERV. 12 (Mar. 10, 2015), http://aspe.hhs.gov/sites/default/files/pdf/83656/ib_2015mar_ enrollment.pdf [http://perma.cc/GAD7-MXCR], But cf. Liz Hamel et al., Survey of Non-Group Health Insurance Enrollees, KAISER FAMILY FounD. (Jun. 19, 2014), http://kff.org/health-reform/report/survey-of-nongroup-health-insurance-enrollees/ [https://perma.cc/END2-B75K] ("[G]ender distribution is similar for those in ACA-compliant plans purchased inside and outside the Marketplace."). 
potentially exacerbating the disparity. ${ }^{70}$ However, with the pool of uninsured women shrinking at a faster rate than that of men, those additional enrollees in HIM plans may statistically be more likely to be men.

To assist with the purchase of healthcare insurance in the HIM, a system of subsidies and tax credits was established by PPACA. ${ }^{71}$ The monies were designed to benefit those between $100 \%$ and $400 \%$ of the federal poverty guideline. ${ }^{72}$ Those above $400 \%$, or $\$ 47,080$ for a single adult and $\$ 97,000$ for a family of four in $2015,{ }^{73}$ were presumed to not require help with the purchase of insurance and/or to be already covered. The subsidies and credits are generally not considered generous for those between $100 \%$ and $138 \%$, where coverage was intended to be provided by Medicaid, because the financial assistance is graduated proportionate to income, and the raw dollar amount may be insufficient to purchase coverage. ${ }^{74}$ Thus in states that did not expand Medicaid, discussed more fully infra, people with incomes under $138 \%$ of the federal poverty guidelines are effectively disenfranchised from healthcare coverage, even in the HIM. The cost-reduction assistance in the HIM favors women superficially, with subsidies averaging $\$ 9,000$ for women and $\$ 8,250$ for men. ${ }^{75}$ The variation, however, should not have significant effect on access to care for one gender more than the other because the cost-reduction system is based on income proportional to household size.

70 Insurance Coverage Provisions of the Affordable Care Act: CBO's March 2015 Baseline, CONG. BUdGET OfFICE 4 (Mar. 9, 2015), https://www.cbo.gov/sites/default/files/cbofiles/attachments/43900-201503-ACAtables.pdf [http://perma.cc/3ZKN-GELR].

71 PPACA $§ 1402$ (b) (codified at 42 U.S.C. $\$ 18071$ (2015)).

72 Id.

7380 Fed. Reg. 3236, 3237 (Jan. 22, 2015).

74 See, e.g., Phil Galewitz, In States that Don't Expand Medicaid, Some of the Uninsured May Still Get Help, KaISER Health News (Aug. 11, 2013), http://kaiserhealthnews.org/news/income-projections-lowincome-obamacare-state-medicaid-marketplace-exchange/ [http:// perma.cc/VQ2X-D7UM] (noting that "even if people with incomes at the poverty level qualify for subsidies for private insurance, the coverage might still be unaffordable . . because they would owe as much as 2 percent of their income towards the cost of the premium and could still have co-pays and deductibles.").

75 Gender Differences and the ACA, supra note 65, at tbl. 3. 
The recent case of King v. Burwell 6 could have fundamentally altered this analysis, however. At issue was the applicability of the system of subsidies and credits to states who opted not to run their own HIM. The plaintiffs argued that the plain language of PPACA makes the costreduction scheme available only in states where the federal government is not a partner or in charge of the HIM. ${ }^{77}$ A holding in favor of the plaintiffs would have eliminated the subsidies and tax credits in as many as thirty-four states, causing an estimated $\$ 28.8$ billion in lost subsidies and credits for over 9 million people. ${ }^{78}$ The majority of HIM plan beneficiaries would thus no longer have been able to afford their plans, potentially shrinking the HIM by threequarters. ${ }^{79}$ So while residents of Washington, D.C., and the sixteen states that manage their own HIM would have been unaffected with regard to the subsidies and credits, the resultant increase in premiums caused by the inevitable loss

76 King v. Burwell, 759 F.3d 358 (4th Cir. 2014) (U.S. argued Mar. 4, 2015). Companion cases include Halbig v. Burwell, 758 F.3d 390 (D.C. Cir. 2014), vacated, and Oklahoma ex rel. Pruitt v. Burwell, 51 F. Supp.3d 1080 (E.D. Okla. 2014).

77 King, 759 F.3d. at 364 . In an opinion that was vacated, the Halbig court held in favor of the similarly situated plaintiffs. Halbig, 758 F.3d at 412. The Pruitt court held in favor of the similarly situated plaintiffs. Pruitt, 51 F.Supp.3d at 1093.

${ }^{78}$ Linda J. Blumberg et al., Urban Inst., The Implications of a Supreme Court Finding for the Plaintiff in King vs. Burwell: 8.2 Million More Uninsured and 35\% Higher Premiums, ROBERT WOOD JOHNSON FoUND. 2-5 (Jan. 2015), http://www.urban.org/sites/default/files/ alfresco/publication-pdfs/2000062-The-Implications-King-vs-Burwell.pdf [http://perma.cc/8UPX-3BX9], Cf. Evan Saltzman \& Christine Eibner, The Effect of Eliminating the Affordable Care Act's Tax Credits in Federally Facilitated Marketplaces, RAND CORP. 3-4 (2015), http:// www.rand.org/content/dam/rand/pubs/research_reports/RR900/RR980/R AND_RR980.pdf [http://perma.cc/U8LX-R82T] (predicting a loss of 9.6 million people from the HIM).

79 See Blumberg et al., supra note 78 , at 5 (75\% decrease); Saltzman \& Eibner, supra note 78 , at $5(70 \%)$. 
of healthy people in the HIM would have negatively affected participants nationwide. ${ }^{80}$

Had the immediate destabilization of the insurance market oft predicted occur, ${ }^{81}$ the rippling effects may have drowned access to care for men and women alike. But such a ruling was more likely to have a disparate effect on the access to care of women for two reasons. First, women are more likely to be uninsured and are also more likely to be poor, ${ }^{82}$ and the greatest direct consequence of a plaintiff victory in King would have been in states where the highest proportion of uninsured and low-income people live. 83 Second, and as noted supra, women enrolled in HIM plans in greater numbers.

Reasons for the disproportionate enrollment are multifactorial. Women are generally the healthcare decisionmakers in any given household. The U.S. Department of Labor estimates that women make $80 \%$ of such decisions while other studies suggest the rate is as high as $90 \%{ }^{84}$ Unsurprisingly, given the overwhelming nature of the disparity, the skewed phenomenon is not new. ${ }^{85}$ Presumably, then the generations of greater experience with healthcare decisions translates to a greater likelihood of enrollment in a

80 Blumberg et al., supra note 78, at 7; Saltzman \& Eibner, supra note 78 , at 5 .

81 E.g., Blumberg et al., supra note 78, at 7 (terming such a scenario a "death spiral"); Saltzman \& Eibner, supra note 78, at 6 ("death spiral"). The Supreme Court itself characterized the potential as a "death spiral," using the term no fewer than twice in the majority opinion. King, $135 \mathrm{~S}$. Ct. 2480, 2482 (2015).

82 See infra text accompanying notes $15-20$.

83 Saltzman \& Eibner, supra note 78, at 5-6. These states typically have conservative governors who are ideologically opposed to PPACA.

84 General Facts on Women and Job Based Health, DEP'T LABOR (Dec. 2013), http://www.dol.gov/ebsa/newsroom/fshlth5.html [http://perma.cc/ V3C6-SBZ7]; Matoff-Stepp, Applebaum, Pooler \& Kavanagh, supra note 52 , at 1508 .

85 See generally, e.g., Dana Hostetler, Women: Health Care's New Decision Makers, 57 J. AM. MED. REC. ASS'N 18 (1986) (describing the first annual conference of the American College of Healthcare Executives to discuss the role of women as administrators and consumers of health care). 
HIM plan where other factors previously prevented insurance coverage.

For instance, as a result of PPACA, insurers are prohibited from denying coverage based on a preexisting illness. ${ }^{86}$ While this provision has broad applicability to all persons, women in particular were susceptible to coverage exclusions and increased premiums simply by virtue of having a uterus. One prominent example during the legislative debate over PPACA was the story of one thirtynine-year-old woman who was expressly advised by her insurance company that only sterilization would make her insurable due to a prior medical history that included a single Caesarean section birth. ${ }^{87}$ Another commonly cited example was the insurance declaration of domestic violence, which affects women disproportionately, as a disqualifying preexisting condition. 88 The correlation between womanhood and these kinds of coverage denials was so strong that, once the PPACA preclusion took effect, the then-Secretary of Health and Human Services famously tweeted, "[b]eing a woman is no longer a pre-existing condition." 89

Similarly, the wide-scale practice of gender rating by insurance companies meant that women were more likely than men to be priced out of the non-group healthcare insurance market. Women between the ages of eighteen and sixty-four were charged as much as $57 \%$ more than men, even with maternity coverage excluded. 90 Across the nation, this

86 PPACA, Pub. L. No. 111-148, § 2704 (codified as amended at 42 U.S.C. § 300gg (2015)).

${ }^{87}$ Denise Grady, After Caesareans, Some See Higher Insurance Cost, N.Y. TiMES (June 1, 2008), http://www.nytimes.com/2008/06/01/health/ 01insure.html?_r=1\&scp=1\&sq=Peggy+Robertson\&st=nyt [http:// perma.cc/8T4X-GYNM].

88 E.g., Ryan Grim, When Getting Beaten by Your Husband is a PreExisting Condition, Huffington Post (May 25, 2011, 2:05 PM), http://www.huffingtonpost.com/2009/09/14/when-getting-beaten-byyo_n_286029.html [http://perma.cc/WRG2-ZCVC] (noting that eight states allow domestic violence to be considered a preexisting condition).

${ }^{89}$ Kathleen Sebelius, TwiTTER (May 10, 2013, 12:10 PM), https:// twitter.com/secsebelius/status/332935813069426689 [http://perma.cc/ HL6H-VK29].

90 Turning to Fairness: Insurance Discrimination Against Women Today and the Affordable Care Act, NAT'L Women's L. CTR. 18 (2012), 
practice was estimated as costing women an aggregate one billion dollars per year, again expressly excluding maternity benefits. ${ }^{91}$ By precluding gender rating and consideration of preexisting conditions, ${ }^{92}$ PPACA enhanced the ability of women to afford and qualify for healthcare insurance coverage, suggesting that women's higher enrollment in HIM plans may level off as those previously disenfranchised acquire coverage.

PPACA also increased access to preventative care by requiring that no co-payment be charged for listed services regardless of whether the insured has met his or her deductible. A variety of these provisions are particularly relevant to or expressly designed for women. Eleven preventative health services apply specifically to women: six services for pregnant women; folic acid supplements for women of childbearing age; select sexually transmitted infection screening; breast and cervical cancer screening; domestic violence counseling; and contraception. ${ }^{93}$ Only one test—a one-time screening for abdominal aortic aneurysmapplies to men only. 94

Importantly, several of these gender-restricted services regard preventative care for conditions that are not necessarily gender-specific. Breast cancer, for instance, can and does occur in men; the National Institutes of Health even maintains a website specifically on the subject. ${ }^{95}$ Yet denials

http://www.nwlc.org/sites/default/files/pdfs/nwlc_2012_turningtofairness _report.pdf [http://perma.cc/4G6R-3F6Z].

91 Id. at 7.

92 PPACA, Pub. L. No. 111-148, § 1557 (2010) (codified as amended at 42 U.S.C. $§ 18116$ (2015)).

93 Preventive Health Services for Women, HealthCARE.GOv, https://www.healthcare.gov/preventive-care-women/ [http:// perma.cc/98B6-WLAU] (last visited Nov. 1, 2015). Although advertised as twenty-six services for women, eleven of those twenty-six are available to men also without cost-sharing. Preventive Health Services for Adults, HEALTHCARE.GOV, https://www.healthcare.gov/ preventive-care-adults/ [http://perma.cc/PE4S-3BDF] (last visited Nov. 1, 2015).

94 Preventive Health Services for Adults, supra note 93.

95 Male Breast Cancer Treatment, NAT'L Inst. Health (Nov. 25, 2014), http://www.cancer.gov/cancertopics/pdq/treatment/malebreast/ patient\#_83 [http://perma.cc/YJV8-J4KZ]. Breast cancer accounts for 1\% of all cancers in men and male breast cancer is approximately $2 \%$ of all breast cancers in the United States, Helmneh M. Sinesha et al., 
of access to breast-cancer-related care for men have been reported since the passage of PPACA. In one self-pay case, a Florida man, whose primary care physician suspected breast cancer, was denied a mammogram by six different facilities, all of whom were offering discounted or free mammograms as part of Breast Cancer Awareness Month campaigns. ${ }^{96}$ Apparently the discounts were for females only.

Of the six tests covered for only pregnant women without cost-sharing, only two are irretrievably tied to motherhoodbreastfeeding comprehensive support and counseling, and $\mathrm{Rh}$ incompatibility screening - though admittedly the effect of the rest on fetal development creates a stronger justification for shifting resources toward greater coverage. ${ }^{97}$ But while men may not get cervical cancer, they are subject to other gender-specific cancers, none of which have mandated cost-free coverage for screenings. Indeed, the same virus attributed to cervical cancer also causes penile and testicular cancers, though with less mortality and morbidity. ${ }^{98}$ Similarly, men experience domestic violence as

Black/White Disparities in Receipt of Treatment and Survival Among Men With Early-Stage Breast Cancer, J. ClinICAL ONCOLOGY 1, 1 (2015).

96 Christy Dimond, Southwest Florida Man Denied Mammogram Because of Gender, Fox4 News (Oct. 8, 2013), http:// www.scrippsmedia.com/fox4now/news/Southwest-Florida-man-deniedmammogram-because-he-is-a-man-226976931.html [http://perma.cc/ EW2B-GTH2].

97 The cost-free services for pregnant women are: (1) anemia screening; (2) breastfeeding support and counseling; (3) diabetes screening; (4) hepatitis B screening; (5) Rh incompatibility screening; and (6) urinary tract or other infection screening. Preventive Health Services for Women, supra note 93. As with services for women versus men, the number advertised for expectant mothers-11-is significantly greater than the number actually restricted to the designated group. See supra note 93 and accompanying text.

98 Xiaocheng Wu et al., Human Papillomavirus-Associated Cancers: United States, 2004-2008, MORBIDITY \& MORTALITY WEEKLY REPORT 25861 (Apr. 20, 2012), http://www.cdc.gov/mmwr/pdf/wk/mm6115.pdf [http://perma.cc/7MMC-2RGN]. The human papilloma virus can also cause anal and oropharyngeal (base of the throat) cancers in all people regardless of gender, $i d$. There are no conclusive methods of screening for oropharyngeal or penile cancers, but there is a test for anal cancer for men and women that is comparable to the test for cervical cancer in women, see HPV and Cancer, AM. CANCER Soc'Y 4-5 (Jan. 2015), http://www.cancer.org/acs/groups/content/@editorial/documents/docume 
well as women, and they may actually have a reduced access to care relative to women because men tend to be more reticent to seek help for domestic violence. ${ }^{99}$ They may also be more likely to be denied services or disbelieved. 100

Inversely, yet similarly, women as well as men die from abdominal aortic aneurysm, a condition referenced supra as the sole cost-share-free benefit PPACA bestows on men. Routine screening has been medically recommended for women at risk, including those over the age of sixty-five who smoke or have heart disease. ${ }^{101}$ Yet this screening is not only not free for all women, even women with high risk are subject to co-payment because by law only men are required to be screened without charge.

These sorts of gender-based distinctions in facilitating access to care have failed judicial review on an equal protection basis at least once. In Woods v. Horton, several male victims of domestic violence sued the State of California after they were denied specialized health and social services

nt/acspc-044199.pdf [http://perma.cc/8NMK-LGYP]. Limitations in medical technology that happen to occur along gender lines is not considered a disparity herein, unless some extraneous factor exists, such as funds diverted to research for only one gender.

99 At least one scholar has found that "women, both generally and in clinical samples, report perpetrating violence against their male intimate partners at rates similar to men." Mary Beth Phelan et al., Domestic Violence Among Male and Female Patients Seeking Emergency Medical Services, 20 Violence \& Victims 187, 189 (2005). Additionally, "compared to men, women are more likely to seek health care services for abuse-related injuries than are men." Id.

100 For perspective on the male victim's experience as perceived by the victim, the public, the police, and the female perpetrator, and how each of these can represent a roadblock to services, see Caroletta A. Shuler, Male Victims of Intimate Partner Violence in the United States: An Examination of the Review of Literature through the Critical Theoretical Perspective, 5 INT'L J. CRIM. JUST. SCI. 163, 164-67 (2010).

101 See Brian G. DeRubertis et al., Abdominal Aortic Aneurysm in Women: Prevalence, Risk Factors, and Implications for Screening, $46 \mathrm{~J}$. VASCULAR SURGERY 630, 630 (2007) ("Although the medical literature suggests a low prevalence rate of AAA in women in the general population, . . . subgroups of women can be identified that are at a substantially increased risk of aneurysmal disease. . . These data support the notion that women with such risk factors should be considered for AAA screening."). 
related to their victimization expressly on the basis of their gender. ${ }^{102}$ On appeal from a denial of the plaintiff's petition, the court held that there is no compelling state interest in funding a domestic violence program for only women, and thus that the programs fail strict scrutiny analysis. ${ }^{103}$ As the court noted in response to the State's assertion that women have a greater need and that insufficient resources require rationing, "equal protection is not concerned with numbers."104

Although our healthcare system is ostensibly and fairly concerned with one very important number-cost - what is clear is that only some gender-based access to care determinations are a result of variations in biophysical or sex-based needs. 105 Other access rules, such as the majority of cost-free screening provisions of PPACA, are more like the programs in Woods. That is, they are gender-based distinctions that create inequities in access to care that are unnecessary, avoidable, unfair, and unjust, and thus are the epitome of a health disparity. Moreover, they exacerbate the already unequal distribution of limited financial resources for enabling access to care by missing the opportunity to address the most severe, or preempt the most costly, healthrelated conditions.

With only one such example of cost-free coverage for men, men overall potentially saw a decrease in the affordability of health insurance due to the weighted balance of cost-sharefree benefits for women, combined with another PPACA requirement that all insurance plans cover minimum essential health benefits to include obstetrical care. ${ }^{106}$ Arguing that men should not have to pay for coverage they would never need, some men-and, curiously, a few women, too-were outraged.107 Of course, the same argument could

102 Woods v. Horton, 84 Cal. Rptr. 3d 332, 337-38 (Cal. Ct. App. 2008).

103 Id. at 346-48.

104 Id. at 347.

105 The presumed need for rationing with a concrete example in the context of the right to health is discussed infra at text accompanying notes 228-240.

$106 I d$. at $\S 1302$ (codified as amended at 42 U.S.C. $\S 18022$ (2015)).

107 See, e.g., Garance Franke-Ruta, Why Is Maternity Care Such an Issue for Obamacare Opponents?, The ATLANTIC (Nov. 22, 2013), http://www.theatlantic.com/politics/archive/2013/11/why-is-maternity- 
be applied to women who are outside of childbearing age, are infertile, or simply will not have children in the future, all of whom similarly experienced reduced affordability due to the insurance market principle of spreading the risk. This somewhat mitigates the effect on men.

Nonetheless, one study predicted that all men would see an increase of $11 \%$ in premiums and women overall would experience a decrease of $9 \% .{ }^{108}$ In particular, women of childbearing age were anticipated to receive a $13 \%$ to $19 \%$ decrease in premiums. 109 Another study found that young men would be particularly susceptible to premium increases of up to $75 \%$ due to the combination of the prohibition on gender-rating and the separate limitations on age-rating. ${ }^{110}$ With only less than two years of HIM existence as of winter 2015 , data are not yet available to support or counter these predictions.

Despite the efforts to increase the affordability and availability of healthcare insurance, it has become clear that many of PPACA's mandates of cost-share-free care are religiously and flagrantly violated. The National Women's Law Center recently examined the 2014 and 2015 certificates of coverage of over one hundred insurance companies in fifteen states, focusing on the insurer's compliance with PPACA in facilitating access to health care for women. ${ }^{111}$

care-such-an-issue-for-obamacare-opponents/281396/ [http://perma.cc/ S26N-YCXE] (citing male and female politicians and commentators who complained about the maternity coverage requirement).

108 JAMES T. O'CONNOR, COMPREHENSIVE ASSESSMENT OF ACA FACTORS THAT WILl AFFECT INDIVIDUAL MARKET PREMIUMS IN 2014, at 21 (2013), available at http://ahip.org/Workarea/DownloadAsset.aspx?id= 2147491347 [http://perma.cc/3QB6-XN5X].

109 Id.

110 Gary Claxton, Larry Levitt, Karen Pollitz \& Anthony Damico, Why Premiums Will Change for People Who Now Have Nongroup Insurance, KAISER FAMILY FOUND. (Feb. 6, 2013), http://kff.org/healthreform/perspective/why-premiums-will-change-for-people-who-nowhave-nongroup-insurance/ [http://perma.cc/9WHS-5MVJ].

111 State of Women's Coverage: Health Plan Violations of the Affordable Care Act, NAT'L WOMEN's L. CTR. (2015), http:// www.nwlc.org/sites/default/files/pdfs/stateofcoverage2015final.pdf [http://perma.cc/3VRD-KCAL]. The states examined were those who make the coverage certificates publicly available, and include Alabama, 
The violations were broken into multiple bullet points across six categories: (1) maternity coverage, such as the exclusion of maternity coverage for dependent enrollees and the establishment of arbitrary limits on benefits; (2) preventative services coverage, such as the imposition of cost-sharing and the limitation of frequency of wellness visits; (3) abortion coverage, such as the creation of varying coverage based on subsidy status; (4) essential health benefit coverage, such as the establishment of limitations stricter than benchmark coverage and the imposition of waiting periods for certain services; (5) discriminatory benefit design, such as the restriction of coverage based on age and the exclusion of chronic pain treatment; and (6) contraceptive coverage, such as the requirement of cost-sharing or the exclusion of certain methods of birth control.112

While the report explored coverage of women's health services pursuant to the requirements of PPACA, the instances of noncompliance are significant here insofar as they are limitations on access to care based on the gender of the patient, as all pertain to the effective insurance coverage of mandatory access to health care. That is, while obstetrical services, for example, may be understood as a gender-specific medical need, the barrier to access to care is not based solely on a legitimate biophysical distinction, but instead is a violation of law that seeks to remedy such disparities in access to health care.

Similarly, the 2014 Supreme Court decision in the case of Burwell v. Hobby Lobby Stores, Inc. ${ }^{113}$ undermines access to

California, Colorado, Connecticut, Florida, Maine, Maryland, Minnesota, Nevada, Ohio, Rhode Island, South Dakota, Tennessee, Washington, and Wisconsin, id.

112 Id. at 4-6 (maternity), 6-14 (preventative), 15 (abortion), 16-18 (essential health benefits), 18-20 (discriminatory benefit design). The matter of coverage of contraception was more fully addressed in a second, simultaneously released report, see State of Birth Control Coverage: Health Plan Violations of the Affordable Care Act, NAT'L WOMEN's L. CTR. (2015), http://www.nwlc.org/sites/default/files/pdfs/ stateofbirthcontrol2015final.pdf [http://perma.cc/N255-X3TQ].

113 Burwell v. Hobby Lobby Stores, Inc., 134 S. Ct. 2751 (2014). Consolidated with this case and ultimately remanded by it were Conestoga Wood Specialties Corp. v. Sec'y of U.S. Dept. of Health and Human Servs., 724 F.3d 377 (3rd Cir. 2013), rev'd, 2014 WL 4467879 (3rd 
gynecological care, which is admittedly gender-specific, by subjugating health care access vis-à-vis mandatory costshare-free coverage. At issue were certain forms of contraception that the owners of the plaintiff businesses believe, as a matter of religion, to be abortifacients. These include all types of intrauterine devices and the emergency contraceptive pills Plan B and Ella. ${ }^{114}$ Regulations pursuant to PPACA require coverage of twenty forms of contraception, including those to which Hobby Lobby began to object after the act was passed, and it contemplated litigation. ${ }^{115}$ Despite the plain meaning of the term "contraception" to expressly exclude actual abortifacients, thereby rendering any burden on religion a legal (and medical) fiction, the Court held in favor of the plaintiffs. ${ }^{116}$ That holding and subsequent regulation extended the coverage exception already in place for religiously oriented non-profit entities like charities, hospitals, schools, and colleges to for-profit closely held corporations. ${ }^{117}$ Female employees of such entities are still eligible to receive cost-share-free contraceptive coverage through alternative means that do not require cost-sharing by the employer, the insurance plan, or the employee. ${ }^{118}$ Nonetheless, the inability to access this type of health care in regular fashion does represent a barrier to care for women

Cir. 2014) and Autocam Corp. v. Burwell, 730 F.3d 618 (6th Cir. 2013), vacated, 134 S. Ct. 2901 (2014).

114 Hobby Lobby Stores, Inc. v. Sebelius, 723 F.3d 1114, 1125 (10th Cir. 2013), aff d, Burwell v. Hobby Lobby Stores, Inc., 134 S. Ct. 2751 (2014).

115 Coverage of Certain Preventive Services Under the Affordable Care Act, 78 Fed. Reg. 39870 (July 2, 2013). Hobby Lobby covered emergency contraception for a long time and only discontinued coverage as part of its litigation strategy, which it admitted in its pleadings. Additionally, it invests significantly in the makers of the contraceptives. See Molly Redden, Hobby Lobby's Hypocrisy: The Company's Retirement Plan Invests in Contraception Manufacturers, Mother JONEs (Apr. 1, 2014, 6:00 AM EDT), http://www.motherjones.com/politics/2014/04/ hobby-lobby-retirement-plan-invested-emergency-contraception-andabortion-drug-makers [http://perma.cc/BD3A-VNQ8].

116 Burwell v. Hobby Lobby Stores, Inc., 134 S. Ct. at 2759-60.

11779 Fed. Reg. 51092 (2014).

118 Id. 
employed by these categories of businesses, the breadth of which is unknown. ${ }^{119}$

In sum, all women are not in fact receiving increased access to preventative care despite the PPACA provisions that expressly sought to remedy gender-based disparities in access. Importantly, however, not all of the decreased access to health care experienced by women occurs around services that are based on biophysical distinctions, though arguably the most egregious examples are. From a gender-parity standpoint, these types of distinctions, while clearly not in alignment with genuine gender-distinct medical needs, are not examples of disparities in access to health care that result from dissimilar legal treatment of similarly situated, but gender-opposed, parties. Other disparities, including costshare-free coverage of the sole screening available only to men, do unnecessarily represent a greater barrier to access to specific medical treatment by women. Likewise, denials of benefits, such as chronic pain treatment, that have a disparate impact on women further defeat access to care.

On the other hand, the rather overwhelming prejudice toward increased access to care for women in PPACA may effect lack of affordability of healthcare insurance for men. Insofar as insurance is a proxy for access to care, the resulting effect of reduced availability of non-group insurance represents a potential barrier to health care access for men. Arguably, however, leveling the playing field does not create disparity. Confounding this conclusion, however, is one study that suggests that men actually have a slightly greater access to healthcare providers in the non-group insurance market, a trend that has been predicted to hold. ${ }^{120}$ Nonetheless, a study similar to one by the National Women's Law Center that considers coverage for all adults would be useful in ascertaining whether the intended increase in

119 The opinion left undefined "closely held," which has multiple legal definitions. For the conclusion of one news outlet that as many as 60 million employees would fall into the category, see Jillian Berman, The Hobby Lobby Decision Could Affect Millions of Workers, Huffington Post, http://www.huffingtonpost.com/2014/06/30/hobby-lobby-closelyheld_n_5545064.html [http://perma.cc/9SZS-NV6Y] (last updated Jul. 10, 2014, 9:59 PM).

120 Gender Differences and the ACA, supra note 65 , at 5 . 
access to wellness care for men (and also for women on care that is not gender-specific) is indeed being compliantly provided.

\section{Medicaid [In]Efficacy in Facilitating Access to Care in the PPACA Era}

Fundamental to the functioning of the HIM was expansion of the Medicaid system. ${ }^{121}$ Since 1965, Medicaid has provided a limited safety net of healthcare insurance for select poor citizens. ${ }^{122}$ A complex system of coverage, Medicaid was, before the PPACA expansion provisions, not available with matching federal funds for non-disabled, childless adults without a waiver. ${ }^{123}$ Of the many waivers granted for use of Medicaid dollars, one prominent program is the National Breast and Cervical Cancer Early Detection Program. ${ }^{124}$ According to the CDC, over four million women were served by the program in its first twenty years. ${ }^{125}$ While the program regulations specify that treatment is available for people of all genders, at least one man was initially denied chemotherapy treatment coverage due to purported state and federal regulations that jointly limited such care to women. ${ }^{126}$ Nonetheless, the program's very existence is an

121 Brandon \& Carnes, supra note 121, at xxxiii.

122 Social Security Amendments of 1965, Pub. L. No. 89-87, 79 Stat. 286 (codified as amended at 42 U.S.C. $\$ \S 1396-1396 \mathrm{w}(2015)$ ).

123 Where are States Today? Medicaid and CHIP Eligibility Levels for Children and Non-Disabled Adults, KAISER FAMILY Found. 2 (Mar. 2013) https:// kaiserfamilyfoundation.files.wordpress.com/2013/04/799303.pdf [http:// perma.cc/2T7W-H2PE] [hereinafter KFF Medicaid 2013].

12442 U.S.C. $\S \S 1396 a(a)(10)(\mathrm{A})(\mathrm{ii})(X V I I I)$, (aa) (2015).

125 Millions of Underserved Women in the U.S. Have Benefited from CDC's Breast and Cervical Screening Program, CTR. DisEASE CONTROL \& PREvention (Aug. 6, 2014), http://www.cdc.gov/media/releases/2014/ p0806-cancer-screening.html [http://perma.cc/JP4E-FE23].

126 South Carolina eventually agreed to cover the treatment. Amanda Chan, Raymond Johnson to Receive Breast Cancer Treatment Coverage, After All, HUfFINGTON POST, http://www.huffingtonpost.com/2011/08/23/ raymond-johnson-breast-cancer-coverage_n_933999.html [http:// perma.cc/APN4-6HPG] (last updated Oct. 24, 2011, 5:12 AM). The initial coverage denial may have been wrong, however. The text of the Breast and Cervical Cancer Prevention and Treatment Act of 2000, which allowed States to opt into Medicaid eligibility for "certain breast or 
example of increased access to expensive care for women who otherwise would be unable to afford screening and treatment, because there is no equivalent program for any other condition.

Limited waiver programs notwithstanding, the multitude of other requirements for potential parent beneficiaries, such as having a monthly income amount that could literally and easily be counted by the dozen, effectively rendered Medicaid nonexistent for most people. ${ }^{127}$ In both Texas and Alabama, for example, the income limit for adult eligibility is currently $18 \%$ of the federal poverty guideline, a maximum income of $\$ 364$ per month for a family of four in 2015.128 Unsurprisingly, then, only $13 \%$ of women and $10 \%$ of men were covered by Medicaid in 2013. ${ }^{129}$

PPACA attempted to increase access to care by removing the various restrictions on Medicaid eligibility and raising the upper income limit for all households to an effective $138 \%$

cervical cancer patients," provides coverage for "individuals," Breast and Cervical Cancer Prevention and Treatment Act of 2000, Pub. L. 106-354, 114 Stat 1381 (2000). Nonetheless, the prefatory language describing the act's intent references only women, as does the CDC's current website on the program, Breast and Cervical Cancer Prevention and Treatment Act of 2000, Ctr. Disease Control \& Prevention (Nov. 5, 2013), http://www.cdc.gov/cancer/nbccedp/legislation/law106-354.htm [http://perma.cc/5E39-4FS2].

127 See KFF Medicaid 2013, supra note 123 (noting in 2013 that "[t]he federal minimum level at which states must cover parents through Medicaid today is below poverty in every state and below half of poverty in nearly all states," meaning that expansion would "significantly increase eligibility for parents" and provide even larger coverage gains for other adults). Cf. Where Are States Today? Medicaid and CHIP Eligibility Levels for Adults, Children, and Pregnant Women, KAISER FAMILY FOUND. (Apr. 2015), http://files.kff.org/attachment/fact-sheetwhere-are-states-today-medicaid-and-chip-2 [http://perma.cc/9WVLDQVW] [hereinafter KFF Medicaid in 2015] (noting in 2015 that in the twenty-two states that have not adopted the Medicaid expansion, the median eligibility limit for parents is $44 \%$ [of the federal poverty guideline], and, with only one exception, childless adults are ineligible for Medicaid, which largely reflects the status prior to expansion under PPACA). Forty-four percent of the federal poverty guideline for a fourperson household in 2015 is $\$ 889.17$ per month.

$128 \mathrm{KFF}$ Medicaid in 2015, supra note 127, at 1.

129 KFF Coverage of Women, supra note 68; KFF Coverage of Men, supra note 68. 
the federal poverty guideline as of January $1,2014 .{ }^{130}$ The purpose of the change was to ensure coverage for those too poor to be sufficiently assisted by the subsidies and tax credits available in the HIM. ${ }^{131}$

However, the Supreme Court ruling in National Federation of Independent Businesses v. Sebelius, one of many legal challenges seeking to dismantle PPACA in its entirety, made optional the Medicaid expansion. ${ }^{132}$ With seventeen states rejecting the Medicaid expansion option as of fall 2015 and another four merely considering the option, ${ }^{133}$ healthcare coverage rates remain low for men and women alike in many states. Texas, for example, has retained its title as the state with the most uninsured citizens-a whopping $24.4 \%$, or over 6.2 million people-by declining to expand Medicaid. ${ }^{134}$ The Texas Medicaid roster tracked the national average prior to the enactment of PPACA with men making up only about $40 \%$ of enrollees, making Texas a good indicator of the proportionate effect of the lack of Medicaid expansion on access to care by gender. ${ }^{135}$

130 PPACA §2001(a), 42 U.S.C. § 1396a (2015) (changing the maximum income to $133 \%$ FPL); PPACA § 2002 (a), 42 U.S.C. $\S 1396(\mathrm{a})(\mathrm{e})$ (2015) (standardizing the system of income disregards to include only a $5 \%$ disregard). For a single-person household, $138 \%$ is $\$ 1,354$ per month in 2015 . For a family of four, it is $\$ 2,789$ per month. Annual Update of the HHS Poverty Guidelines, 80 Fed. Reg. 3236, 3237 (Jan. 22, 2015).

131 Brandon \& Carnes, supra note 67, at xxxiii. See also supra notes 71-75 and accompanying text.

132 Nat'l Fed'n of Indep. Bus. v. Sebelius, 132 S. Ct. 2566 (2012).

133 Status of State Action on the Medicaid Expansion Decision, KAISER FAMILY FOUND., http://kff.org/health-reform/state-indicator/ state-activity-around-expanding-medicaid-under-the-affordable-careact/ [http://perma.cc/7HSK-CUEY] (last updated Sept. 1, 2015).

134 Dan Witters, Arkansas, Kentucky See Most Improvement in Uninsured Rates, GALLUP (Feb. 24, 2015), http://www.gallup.com/ poll/181664/arkansas-kentucky-improvement-uninsured-rates.aspx? utm_source=Well-Being\&utm_medium=newsfeed\&utm_campaign=tiles [http://perma.cc/5US7-KPDF]; Alexa Ura, Texas Still Tops Census List of Highest Uninsured Rates, TEX. TRIB. (Sept. 16, 2014), http:// www.texastribune.org/2014/09/16/texas-tops-census-list-highestuninsured-rate/ [http://perma.cc/JHP4-T7GP].

135 See Medicaid Enrollment by Gender, KaIser FAMILY Found., http://kff.org/medicaid/state-indicator/medicaid-enrollment-by-gender/ 
In expansion states, the uninsured proportion is dramatically different. Combined with the Children's Health Insurance Program, which provides insurance for children through the age of nineteen and some or all services for pregnant women, Medicaid enrollment rose by over $26.1 \%$ in the first year since the January 1, 2014, effective date of the expansion. ${ }^{136}$ The national uninsured average has since dropped to $11.9 \%$, a figure that includes the twenty-one nonexpansion states. 137 Amongst states that have expanded Medicaid are Massachusetts, which has had the lowest uninsured rate since shortly after the enactment of a state version of PPACA, with an uninsured rate of $4.6 \%$, followed by Connecticut and Hawaii at 6\%.138 Thus, Medicaid expansion has had a dramatic effect on financial access to care.

It has in particular increased access to care for men of modest income. Prior to PPACA, the common requirement that an adult be the primary conservator in order to qualify for Medicaid was a factor in inflating the proportion of women receiving Medicaid, largely because women are more likely than men to be the single parent in possession of a child. 139 This is still true in non-expansion states. But, though the data are limited, it appears that in expansion states, men are experiencing a greater increase in access to care through Medicaid enrollment. In Illinois, for instance,

[http://perma.cc/M5ZJ-N4VU] (last visited Nov. 1, 2015) (listing men as $41 \%$ of the national population and $43 \%$ of Texans enrolled in Medicaid).

136 Ctr. Medicare \& Medicaid Serv., DeP’T Health \& Hum. SERV., MEDICAID \& CHIP: JANUARY 2015 MONTHLY APPLICATIONS, EligiBILITY DETERMINATIONS AND ENROLLMENT REPORT 3 (2015), available at http:// medicaid.gov/medicaid-chip-program-information/program-information/ downloads/medicaid-and-chip-january-2015-application-eligibility-andenrollment-data.pdf [http://perma.cc/7ZVK-62N5].

137 Jenna Levy, In U.S., Uninsured Rate Dips to 11.9\% in First Quarter, GALLUP (Apr. 13, 2015), http://www.gallup.com/poll/182348/ uninsured-rate-dips-first-quarter.aspx [http://perma.cc/B9QT-MZDU].

138 Witters, supra note 134.

139 Rachel Garfield \& Anthony Damico, The Coverage Gap: Uninsured Poor Adults in States that Do Not Expand Medicaid-An Update, KAISER FAMILY FOUND. 4 (Oct. 2015), http://files.kff.org/ attachment/issue-brief-the-coverage-gap-uninsured-poor-adults-instates-that-do-not-expand-medicaid-an-update [http://perma.cc/7F55XWL9]. 
Medicaid enrollees in April 2015 were 55.7\% male and only $44.3 \%$ female. ${ }^{140}$ Given the removal of the conservatorship and other severely limiting eligibility requirements, which favored women, it is logical that Medicaid expansion would cause men to have increased financial access to health care.

Compounding the problem of coverage in non-expansion states is the system of subsidies and tax credits set out by PPACA for insureds in the HIM. As described supra, the subsidies and credits available for people between $100 \%$ and $138 \%$ of the federal poverty guideline are not generous in terms of raw dollar amount relative to the cost of non-group insurance in the HIM. ${ }^{141}$ This was not a design flaw, however, as these citizens were intended to be covered by Medicaid; the aforementioned National Federation of Independent Businesses ruling interfered with the framework by allowing states to opt out of the expansion, creating a fiscal gap in the availability of healthcare insurance.

While the severity of the problem for the four million people who are estimated to be Medicaid-eligible should not be minimized, men and women are, on the surface, equally affected, with $49 \%$ of those in the coverage gap female and $51 \%$ male. ${ }^{142}$ Nonetheless, in non-expansion states, $85 \%$ of men who would be eligible for Medicaid under the expansion schema fall within the gap while only $78 \%$ of women do. ${ }^{143}$ Thus, this additional barrier to access to health care may be understood as a greater burden for men than women because

140 Ill. Healthcare \& FaM. SERV., AfFordable CARE ACT ENROLLMENT BY AGE, RACE, AND GENDER AS OF APRIL 2015 (Apr. 2015) (on file with author).

141 See supra notes 71-74 and accompanying text.

142 Garfield \& Damico, supra note 139, at 4.

143 Id. Wisconsin represents a partial exception, however, because although the state did not expand the Medicaid maximum permitted income to 138 percent of the federal poverty guideline, it does provide coverage equally for all adults, regardless of gender, whose income is below the federal poverty guideline. For background, see Erin Toner, Wisconsin Chooses its Own Path to Overhaul Medicaid, NPR (Nov. 19, 2013, 2:56 AM), http://www.npr.org/blogs/health/2013/11/19/246003602/ wisconsin-chooses-its-own-path-to-overhaul-medicaid [http://perma.cc/ 293U-R6K7]. 
under the current rules in non-expansion states, women are more likely to qualify for Medicaid.

Importantly, the access to care provided by Medicaid is "fairly comparable to that of low-income Americans with employer-sponsored insurance." 144 It is also significantly better than the access of the uninsured: In the first year of the expansion, hospital uncompensated care costs dropped $\$ 7.4$ billion dollars, a $21 \%$ reduction; Medicaid expansion is credited with $68 \%$ of that savings. ${ }^{145}$ In addition, both proportions and volumes of uninsured or self-pay emergency department visits and hospital admissions fell substantially. ${ }^{146}$ While the importance of the reduced cost to the healthcare system cannot be overstated, on both an individual and population level, utilization cost reduction is indicative of the significance of the increased access to primary care that the Medicaid expansion catalyzed. Somewhat surprisingly, however, although the Medicaid expansion seems thus far to have favored men, as discussed infra, the decrease in uncompensated care suggests that it is women whose access to primary care has been increased. This is because women are as much as $150 \%$ more likely than men to have two or more emergency department visits or hospital admissions in any given twelve-month-period. ${ }^{147}$

144 DeP'T Health \& Hum. Serv., 2014 Annual Report on THE QUALITY OF HEALTH CARE FOR ADULTS ENROLLED IN MEDICAID 10 (2014), available at http://www.medicaid.gov/medicaid-chip-programinformation/ by-topics/quality-of-care/downloads/2014-adult-sec-rept.pdf [http://perma.cc/6CG2-UEHG].

145 DeP’T HeAlth \& HuM. SERV., Insurance ExPANSION, Hospital UNCOMPENSATED CARE, AND THE AFFORDABLE CARE ACT (2015), available at http://aspe.hhs.gov/health/reports/2015/medicaidexpansion/ ib_uncompensatedcare.pdf [http://perma.cc/8K6V-NPPN]. For the full report, which defines "uncompensated care" as the "combined total of bad debt and charity care," see Thomas DeLeire et al., Impact of Insurance Expansion on Hospital Uncompensated Care Costs in 2014, DEP'T HEALTH \& HuM. SERV. (Sept. 24, 2014), http://aspe.hhs.gov/ health/reports/2014/UncompensatedCare/ib_UncompensatedCare.pdf [http://perma.cc/N8E8-MGM8].

146 Insurance ExPANSION, Hospital UnCOMPENSATED CARE, AND THE AFFORDABLE CARE ACT, supra note 145, at 1.

147 Health, United States, 2014, CTR. Disease CONTROL \& PREVENTION 276 (May 2015), http://www.cdc.gov/nchs/data/hus/ hus14.pdf [http://perma.cc/2ZZG-WHPW]. 
That does not, of course, mean that the access to care that Medicaid provides is equivalent to that experienced by people in either the group or non-group markets. Indeed, federal and state reductions in rates of reimbursement have caused fears that the pool of physicians accepting Medicaid would decrease, which is particularly troubling given that an important component of access to care is having a dedicated healthcare provider. ${ }^{148}$ Others have predicted that swelling Medicaid rolls would cause the remaining primary care providers to be overwhelmed, decreasing access for all patients as wait-times increased. 149 Neither concern has borne out, but, were they to, women would likely be disproportionately affected in their access to care, because women are more likely to have a dedicated primary care physician. 150 On the other hand, men's reticence to seek medical care may further exacerbate any provider access issues that may develop. ${ }^{151}$

In sum, the restrictions on Medicaid enrollment in nonexpansion states represent a barrier to care for the significant proportion of the population that is excluded, which predominantly is men, though low-income men in expansion states have a significantly increased financial access to care that puts them on par with similarly situated women.

148 Stephen Zuckerman, et al., Reversing the Medicaid Fee Bump: How Much Could Medicaid Physician Fees for Primary Care Fall in 2015?, URBAN INSTITUTE (Dec. 2014), http://www.urban.org/sites/default/ files/alfresco/publication-pdfs/2000025-Reversing-the-Medicaid-FeeBump.pdf [http://perma.cc/PZF5-P2C4].

14914 Million More Have Coverage, Yet Doctors Aren't Swamped, Univ. PitTsburg MeD. CTR. (Apr. 29, 2015), http:// www.yourhealthcaresimplified.org/news/14-million-more-have-coverageyet-doctors-arent-swamped-028new/ [http://perma.cc/C8S3-2FP].

150 CHUN-JU HSIAO ET AL., supra note 37, at 15.

151 See, e.g., Memorandum from Stacey Zabusky, Harris Interactive on Men's Health Study to Janelle Davis, Am. Acad. Family Physicians 3 (May 9, 2007), available at http://www.aafp.org/dam/AAFP/ documents/ media_center/men-prevention/final_executive_summary_061307.pdf [http://perma.cc/FCU7-7RYG] ("The majority of U.S. men (92\%) indicated they wait at least a few days before seeking medical care or advice, although likelihood to seek care or advice right away increases with age."). 


\section{Other Third-Party Payors}

Medicare covers $93 \%$ of adults over the age of sixty-five, largely eliminating disparities in access to care by either gender in that population. ${ }^{152}$ Ninety-six percent of Medicare beneficiaries, whether male or female, report having a usual source of care from whom they can receive timely medical attention. ${ }^{153}$ Because the program covers two medically needy populations - certain long-term disabled adults along with seniors-regular access to a dedicated healthcare provider is a very important indicator of the efficacy of Medicare in creating access to care. ${ }^{154}$ Notably, Medicare beneficiaries' access to care is "comparable to or better than access reported by privately insured individuals." 155 It is also less likely to be financially burdensome. 156

Fifty-six percent of Medicare beneficiaries are female, a disproportion largely due to the longer lifespans enjoyed by women. ${ }^{157}$ Nonetheless, because older women today are less likely to have adequate retirement benefits due to shorter work histories and lower pay, ${ }^{158}$ they may be more susceptible than men to other income-based limitations on access to care, as noted supra.

152 A Profile of Older Americans: 2012, AdmIn. ON AGING 14, http://www.aoa.gov/Aging_Statistics/Profile/2012/docs/2012profile.pdf [http://perma.cc/6X37-BU48].

153 Cristina Boccuti et al., Medicare Patients' Access to Physicians: A Synthesis of the Evidence, KAISER FAMILY Found. 2-3 (Dec. 2013), https://kaiserfamilyfoundation.files.wordpress.com/2013/12/8526-

medicare-patients-access-to-physicians5.pdf [http://perma.cc/V5SF$8 \mathrm{ASH}]$.

154 Id. at $2,15$.

155 AdELE SHARTZER ET AL., ACCESs to PHYSiCIANS' SERVICES FOR MEDICARE BENEFICIARIES 4 (2013), available at http://aspe.hhs.gov/ health/reports/2013/PhysicianMedicare/ib_physicianmedicare.pdf [http://perma.cc/QX2M-ERFJ].

156 THE IMPORTANCE OF MEDICARE FOR WOMEN 1 (2012), available at http://www.nwlc.org/sites/default/files/pdfs/the_importance_of_medicare _for_women_factsheet_08-29-12.pdf [http://perma.cc/APB2-LUMV].

157 Id. See also A Profile of Older Americans: 2012, supra note 152, at 2, 4 (noting that there are 131 older women for every 100 older men, that ratio increase to 203 to 100 at age eighty-five, and that there are four times as many widows as widowers amongst older persons).

158 Women and Retirement Savings, DEP'T OF LABOR 2 (Aug. 2013), http://www.dol.gov/ebsa/pdf/women.pdf [http://perma.cc/U3EC-4762]. 
Tied to Medicare financial access efficiency is the Tricare system, which provides healthcare insurance coverage to current and former service members and their families, or roughly $4 \%$ of the U.S. population. ${ }^{159}$ However, because men are much more likely to serve in the military and the women who do serve are typically single, 160 women receive dependent coverage in greater proportions. With a divorce rate amongst military families that exceeds the general population ${ }^{161}$ and very restrictive provisions on post-divorce eligibility for Tricare, ${ }^{162}$ women's healthcare coverage under Tricare is in general more tenuous than men's. In contrast, men are more likely than women to lose their Tricare coverage due to being discharged at less than honorable status, but this occurs in relatively low numbers. ${ }^{163}$ A recent study made clear that changes to the reimbursement mechanism for civilian providers of health care to Tricare beneficiaries, which were unrelated to PPACA but also effective January 1, 2014, did not affect access to care for either gender. ${ }^{164}$

159 U.S. Gov'T ACCOUNTABILITY OfFiCE, Sole COMMUNity HosPitals: EARLY INDICATIONS SHOW THAT TRICARE'S REVISED REIMBURSEMENT Rules Have Not AFFECTED ACCess to CARE (2015), available at http://www.gao.gov/assets/670/669663.pdf [http://perma.cc/G5SE-843N].

160 Eileen Patten \& Kim PaRkeR, Women in the U.S. Military: Growing Share, Distinctive Profile 4-5 (2011), available at http://www.pewsocialtrends.org/files/2011/12/women-in-the-military.pdf [http://perma.cc/BFF2-Y895].

161 Jennifer Hickes Lundquist, A Comparison of Civilian and Enlisted Divorce Rates During the Early All Volunteer Force Era, 35 J. PoL. \& MiL. Soc. 199, 213 (2007) ("When compared to same aged, married civilians in the presence of multiple demographic, religious, socioeconomic, and attitudinal controls, enlistees are still more likely to divorce than comparable civilians.").

162 See 10 U.S.C. $\S 1072(2)(\mathrm{F})-(\mathrm{I})$ (delineating the post-divorce Tricare eligibility requirements for former spouses, which include twenty years of marriage contemporaneous with as many years of service).

163 See generally Evan R. Seamone et al., Moving Upstream: Why Rehabilitative Justice in Military Discharge Proceedings Serves a Public Health Interest, 104 AM. J. PuB. HeAlth 1805 (2014) (discussing the nexus between less-than-honorable discharges and access to health care through Tricare and the other military health system components, and noting the disproportionate effect on males).

164 Gov'T ACCOUNTABILITY OFF., supra note 159, at 16. 
In conclusion, given the current restrictions on gender rating by insurance companies, disparities in access to health care vis-à-vis insurance cannot bear attenuated attribution to biophysical distinctions. Often, social constructs that tend to influence ability to acquire a health plan are driving this aspect of access to care and generally in favor of men. Some of these are also the types of disparities that law is arguably most able to remedy.

\section{Reproductive Access to Care: The Role of Competing Doctrines}

This paper began with an example of a proposed legislative restriction on an otherwise lawful medical procedure for women-medication abortion by telemedicine. That bill passed along party lines. ${ }^{165}$ Clearly this represents a gender-specific restriction on access to care, though necessarily along the lines of a biophysical distinction in medical need; but it is problematic and notable because the specific medical service is otherwise a constitutional right, and so a direct proscription would not be lawful. So while Idaho became the sixteenth state with a prohibition on obtaining abortion medication through telemedicine, no state disallows the prescription of any other medication via telemedicine. 166 Relative to the spectrum of medical treatments available by telemedicine, women are disadvantaged by this singular prohibition. Somewhat surprisingly, it appears that only one court has attempted to set aside the abortion issue and addressed a similar law from a gender-conscious access-to-care perspective. In Planned Parenthood of the Heartland v. Iowa Board of Medicine, the court acknowledged the potential unequal treatment that inheres in subjecting a single telemedicine procedure to

165 See House Bill 154, IDAHO LEG., http://www.legislature.idaho.gov/ legislation/2015/H0154.htm [http://perma.cc/B6ZU-FRM6] (last visited Jan. 5, 2016) (providing the bill's history to include legislative votes).

166 Latoya Thomas \& Gary Capistrant, Am. TElemed. Ass'N, State Telemedicine Gaps Analysis: Physician Practice Standards \& LiCENSURE 81-82 (May 2015), available at http:// www. americantelemed.org/docs/default-source/policy/50-state-telemedicinegaps-analysis-physician-practice-standards-licensure.pdf?sfvrsn=14 [http://perma.cc/7HEH-5NUK]. 
stricter regulation than other procedures available by telemedicine. 167 But on the matter of the federal and state constitutional equal protection claim, the court essentially held the issue inadequately briefed. 168

A further limitation for women on access to this timesensitive need for care is the extension in the Idaho law of a civil remedy against the physician to the female patient's husband, and, in the event of the patient's demise, her mother. 169 Given the marginalization of women in some subpopulations, noted infra, this potentially represents a significant mechanism to reduce access to care by women. Moreover, the cause of action is not for loss of consortium, or a derivative claim of harm to the fetus (or something equally pious), or even for prescribing abortion medication via telemedicine; but rather the claim is for the knowing or reckless act of performing or attempting to perform an abortion upon a female. ${ }^{170}$ This override of any consent or stated preference of the female body that received the benefit of a lawful medication, albeit through a newly unlawful method, is yet another way that law can be used to create reduced access for women to care. ${ }^{171}$

167 Planned Parenthood of the Heartland v. Iowa Bd. Of Med., No. CVCV046429, 2014 WL 7054656, at *21 (Iowa Dist. Jan. 7, 2014) ("[The plaintiff] claims that the board's rule has violated equal protection because telemedicine abortion is treated differently than other telemedicine ....") aff'd, 865 N.W.2d 252 (Iowa 2015).

168 Id. ("[T] he claim is difficult to evaluate because [the plaintiff] has not precisely defined the groups it claims has been treated differently, a must for an equal protection evaluation .. . There is no evidence indicating to what extent the board allows telemedicine in other contexts, so there is no means to evaluate a broad equal protection claim.").

169 Physician Physical Presence and Women Protection Act, H.B. 154 $\S$ 18-618, 63 $3^{\text {rd }}$ Leg., Reg. Sess. (Idaho 2015) (enacted), http:// www.legislature.idaho.gov/legislation/2015/H0154.pdf [http://perma.cc/ $\mathrm{X} 4 \mathrm{XC}-7 \mathrm{R} 53]$

170 Id.

171 In the context of informed consent laws, women are generally not treated as having full capacity. See Deborah L. Forman, When "Bad" Mothers Make Worse Law: A Critique of Legislative Limits on Embryo Transfer, 14 U. PA. J.L. \& Soc. ChAnge 273, 299 (2014) (citing three primary areas of regulation of informed consent: mental health treatment, medical treatment of minors, and treatment related to women's reproduction). Accord Dan L. Burk, DNA Rules: Legal and Conceptual Implications of Biological "Lock-Out" Systems, 92 CALIF. L. 
Examples of selective proscriptions on women's reproductive care services are available elsewhere. Such deliberate prohibitions on accessing a particular medical treatment may even occur through mechanisms designed to effect the opposite. For example, within four years of the U.S. Supreme Court recognizing a right to privacy in all medical care in Roe v. Wade,172 Congress passed the Hyde Amendment, which prohibits the use of federal public dollars for elective abortion with limited exception. ${ }^{173}$ A longstanding budget rider, recent efforts to codify the Hyde Amendment have failed, ${ }^{174}$ but the Amendment itself was reaffirmed in 2010 by an executive order negotiated alongside PPACA. ${ }^{175}$ Expressly prohibited in that order was the use of tax credits and subsidies to pay for healthcare insurance coverage of abortions. ${ }^{176}$

The Hyde Amendment represents a significant restriction on financial access to women's reproductive care because those directly affected include women insured through Medicaid, Medicare, and Tricare, along with all other women whose medical care is provided by or underwritten by the federal government. For this reason, seventeen states use local funds to restore that access, including four that do so voluntarily without judicial intervention. ${ }^{177}$ The law and

REV. 1553, 1580 (2004) ("The historical inclusion of women together with children and mentally handicapped individuals as legal incompetents amply illustrates the danger of judicial preferences not merely to the success of a particular bargain, but to individual autonomy.").

172 Roe v. Wade, 93 S.Ct. 705 (1972).

173 Pub. L. No. 94-439 § 209, 90 Stat. 1418, 1434 (1976).

174 E.g., Hyde Amendment Codification Act, S. 142, 113th Cong. (2013); Hyde Amendment Codification Act, S. 1488, 112th Cong. (2011). The most recent version, Hyde Amendment Codification Act, S. 219, 114th Cong. (2015), has been given a 1\% chance of being enacted. S. 219: Hyde Amendment Codification Act, GovTrack.US, https:// www.govtrack.us/congress/bills/114/s219 [https://perma.cc/47NX-TQZ5] (last visited May 29, 2015).

175 Exec. Order No. 13535 Ensuring Enforcement and Implementation of Abortion Restrictions in the Patient Protection and Affordable Care Act, 75 Fed. Reg. 15599 (Mar. 29, 2010).

176 Id. $\S 2$.

177 GutTmacher Institute, State Policies in Brief: State FUNDING OF ABORTION UNDER MEDICAID, 1 (2015), available at http:// www.guttmacher.org/statecenter/spibs/spib_SFAM.pdf [http://perma.cc/ KSB8-GUZF]. 
policy in these states stands in stark contrast to the Hyde Amendment, the constitutionality of which was affirmed in 1980 by the U.S. Supreme Court. ${ }^{178}$ Holding that there is no right to the use of public funds to provide for any specific medical treatment under the due process or equal protection clauses because the government does not cause the indigency that makes care unaffordable, the Court nonetheless noted the role of public policy: "[t]he Hyde Amendment . . . encourages alternative activity deemed in the public interest."179

Institutional policy may also militate away from access to care in other ways that specifically and derivatively target male and female reproductive medical care. Directives by the Catholic Church turn permissive statutes regarding conscientious objection into mandates for all employees of Catholic institutions ${ }^{180}$ and for Catholic providers in secular or other institutions. ${ }^{181}$ While the majority of these directives are either gender-neutral toward patients-neither men nor women may be rendered sterile in a Catholic hospital, for example ${ }^{182}$ - those that preclude medical attention at or before conception, or during pregnancy, do disproportionately limit women's access to care, and at times where women are most vulnerable.

The effect on access to care is multiplied by at least two factors. First, Catholic hospitals represent a significant portion of the hospital industry in the United States: Every

178 Harris v. McRae, 448 U.S. 297 (1980).

$179 I d$. at 315 . While "public interest" does not always equate with the concept of public policy, here it seems it does.

180 See U.S. CONFERENCE OF CATHOLIC Bishops, ETHICAL AND Religious Directives For Catholic Health CaRe SERVices, 3 (5th ed. 2009), available at http://www.usccb.org/issues-and-action/human-lifeand-dignity/health-care/upload/Ethical-Religious-Directives-CatholicHealth-Care-Services-fifth-edition-2009.pdf [http://perma.cc/XDW7W3Q4] [hereinafter CATHOLIC DiRECTIVES] ("Since they express the Church's moral teaching, these Directives also will be helpful to Catholic professionals engaged in health care services in other settings.").

181 See id. at 125 ("Catholic health care services must adopt these Directives as policy, require adherence to them within the institution as a condition for medical privileges and employment, and provide appropriate instruction regarding the Directives for administration, medical and nursing staff, and other personnel.").

$182 I d$. at 27. 
state has Catholic healthcare facilities that provide acute care, skilled nursing, and other services. ${ }^{183}$ With five states lacking a Catholic hospital, one in six patients nationwide nonetheless is admitted to a Catholic bed.184 One-third of Catholic hospitals are located in rural areas, where they are likely to be the only acute care facility available. ${ }^{185}$ Even in urban areas, accessing a non-Catholic institution may be complicated by insurance network rules, poor transportation, inadequate paid time off work, and other socio-economic issues that affect access to care, many of which were explicated above as having a disparate effect on women. The pervasive role of the Catholic Church in health care means that there are areas of the country where men and women alike are without an alternative choice, in turn rendering their effective access to care of lessened value.

Second, in addition to federal law, state laws overwhelmingly sanction these access-restricting policies. For instance, every state permits physicians to refuse to provide abortion services, and thirteen states allow providers to refuse to provide contraception. ${ }^{186}$ Additionally, eighteen states have no proscription on providers declining to provide sterilization. ${ }^{187}$ Of course, conscience clauses are not restricted to those providing reproductive care, but because the philosophy became legally recognized post-Roe, it has continued to be so associated. ${ }^{188}$

But by allowing healthcare providers to opt out of providing any health care without regard to the needs of the

183 Catholic Health Ass'N OF The U.S., Catholic Health Care in THE UNITED STATES, 2 (Jan. 2013), available at https://www.chausa.org/ docs/default-source/general-files/mini_profile-pdf.pdf?sfvrsn=0 [http:// perma.cc/8Y4H-3F88].

184 Id. at 1-2.

185 Id. at 2.

186 Guttmacher Institute, State Policies in Brief: Refusing to Provide Health Services, 2 (2015), available at http:// www.guttmacher.org/statecenter/spibs/spib_RPHS.pdf. [http://perma.cc/ M3C9-EAW6]..

187 Id.

188 The first federal conscience exception to treatment was the Church Amendment, passed in 1973. 42 U.S.C. § 300a-7(b) (1973). See generally HOLLY FERNANDEZ LYNCH, CONFLICTS OF CONSCIENCE IN HEALTH CARE: AN Institutional COMPROMise, 19-24 (2008) (describing the history of conscience clauses). 
patient, and especially in ways that can disenfranchise entire subpopulations, access to care begins to become meaningless. After all, increasing access to care is futile if no one will provide the care. Moreover, given the bend toward declining to provide services that broadly affect women, the directives and supporting legislation reduce access disproportionately. Even where the patient is male, restrictions on access to male reproductive care "can only be carried out on the backs of women," because, ultimately, women are physically, emotionally, legally, and financially responsible for pregnancy or lack thereof. 189 Ironically, the resultant increased need for care further concentrates the disproportionality of the burden of the lack of access to care for women.

Religion or other conscientious objection acts as a delimiter on access to reproductive care in other ways, too. As discussed supra, the Hobby Lobby case provided a potentially broad expansion of religious liberty to for-profit corporations that are closely held.190 Unlike the Catholic Church directives, which proscribe effectively all contraception on the basis of interference with sex as having only "unitive and procreative meaning," 191 the holding in Hobby Lobby relies not on consistent religious doctrine, but rather a selective and convenient disbelief of science. ${ }^{192}$ Because of the potentially broad applicability of such a holding, it is conceivable that religion may further restrict access to care in the future. ${ }^{193}$

189 Roth, supra note 34, at 393, 411-13.

190 See supra text accompanying notes 113-119.

191 CATHOLIC DiRECTIVES, supra note 180, at 24.

192 See sources cited supra note 69. See sources cited supra notes 113119.

193 See Hobby Lobby, 134 S. Ct. at 2787 (Ginsburg, J., dissenting) ("In a decision of startling breadth, the Court holds that commercial enterprises, including corporations, along with partnerships and sole proprietorships, can opt out of any law (saving only tax laws) they judge incompatible with their sincerely held religious beliefs."). 


\section{Transgendering Access to Care: The Role of the Non- Binary Gender Perspective}

As a final consideration of gender-based health and health care disparities, it is worth a brief foray into the access issues of those whose gender falls outside of the Western tradition of a binary gender system. It has been estimated that only $0.3 \%$ of American adults are transgender. ${ }^{194}$ Difficulties with defining the transgender population have created challenges in solidifying that number, ${ }^{195}$ but, nonetheless, it is an increasingly mainstream idea that a not insignificant number of people identify as something other than simply male or female. ${ }^{196}$ Exemplifying both the definitional difficulties and pervasiveness of other-genderedness is recent criticism of Facebook: the social networking giant limited its users to one of fifty-eight gender identity options, a number that caused such backlash about its insufficiency that the company felt compelled to make the gender identification option an open question. 197

Thus, any gender-based discussion should at least consider a selective overview of disparities for those who fall outside of the male/female dichotomy, especially, perhaps, in the context of access to health care, which population health research demonstrates is a considerable source of health

194 Gary J. Gates, How Many People are Lesbian, Gay, Bisexual, AND TransGender?, 6 THE Williams Institute (April 2011) (estimating the size of the lesbian, gay, bisexual, and transgender population in the U.S. through review of eleven recent surveys regarding sexual orientation or gender identify questions), available at http:// williamsinstitute.law.ucla.edu/wp-content/uploads/Gates-How-Many-

People-LGBT-Apr-2011.pdf [http://perma.cc/4FBZ-PCW4].

$195 \mathrm{Id}$. at 2.

196 See, e.g., Katy Steinmetz, This Is What 'Cisgender' Means, Time (Dec. 23, 2014), http://time.com/3636430/cisgender-definition/ [http:// perma.cc/RV64-HNWS] (discussing the usefulness of the newly created term "cisgender," included in the Oxford Dictionary only since 2013, to describe those traditionally referred to as "male" or "female").

197 Jessica Guynn, Facebook's New Gender Option: Fill in the Blank, USA TODAY (Feb. 26, 2015, 1:00 PM EST), http://www.usatoday.com/ story/tech/2015/02/26/facebook-gender-option-fill-in-the-blank/24059551/ [https://perma.cc/9ZA4-7KMC]. 
inequality amongst the gender diverse. ${ }^{198}$ Nonetheless, this paper does not seek to fully consider the health concerns of other-gendered persons, not because they are wholly irrelevant, but because they are complex and worthy of fuller treatment than would be appropriate here. Additionally, the thesis of this paper is comparative in nature, so the focus here is on a few issues specific to access that mirror the concerns of people gendered as male or female- that is, those who are similarly situated whose access to health care is limited because of, or as a result of, gender.

The medical goals of trans- or other gender persons can create unique issues of access to specialized health care, but access to primary care is often a preliminary barrier. ${ }^{199}$ As with the reduced access to primary care by women as against men, the reasons are multifactorial. First, the rate of private and employer-based health insurance amongst transgender persons is lower than the national average, as is the mean income. 200 As noted supra, health insurance is a proxy for access to health care, and the more modest a person's income, the less likely that person is to receive preventative care services. ${ }^{201}$ The concordant issues of enhanced likelihood of health-harming behaviors and difficulty with prioritizing health are also present.

Second, as much as the marginalization of women in certain communities contributes to lack of primary care, the transgender community is often further on the outskirts of society. As also noted above, marginalization contributes to difficulty accessing care. Transgender people may be more likely, however, to experience outright and express

198 Frank Pega \& Jaimie F. Veale, The Case for the World Health Organization's Commission on Social Determinants of Health to Address Gender Identity, 105(3) AM. J. PuB. HeALth e58, e59 (2015).

199 Michael Silverman, Issues in Access to Healthcare by Transgender Individuals, 30 WoMEN'S RTS. L. REP. 347, 348 (2009).

200 Rachel C. Kurzweil, Note, "Justice is What Love Looks Like in Public": How the Affordable Care Act Falls Short on Transgender Health Care Access, 21 WASH. \& LEE J. Civil RTS. \& Soc. Just. 199, 214-215 (2014).

201 See supra notes 40-42 and accompanying text. 
discrimination from the healthcare community than either women or men. ${ }^{202}$

Third, the mismatch between a transgender person's appearance and his or her official identification can arouse suspicion, or create inconsistencies that necessitate explanation by the patient and understanding by the healthcare entity representative. ${ }^{203}$ That is, insurance or other documents may classify a person as one gender, but hormonal or even lifestyle options may mean that a transgender person's medical needs more closely align with those of the gender opposed to that on the documentation. While that issue is unique to transgender people, it explains why transgender women may be as likely as men to have difficulties accessing preventative health services that are readily available for cisgender women, such as screening for breast cancer. ${ }^{204}$ This is particularly concerning because hormone therapy may increase the susceptibility to certain conditions, some of which may typically and legally be associated with primarily one gender. ${ }^{205}$

202 Silverman, supra note 199 , at 348. This status is reinforced by judicial decisions that hesitate in applying to transgender persons the same intermediate scrutiny as is applicable to sex or gender discrimination against those who fall within the Western binary gender perspective. See, e.g., Johnston v. Univ. of Pitt., --- F.Supp.3d---, No. 3:13-213, 2015 WL 1497753, at *8 (W.D. Penn. Mar. 31, 2015) ("[N]either the United States Supreme Court nor the Third Circuit Court of Appeals has recognized transgender as a suspect classification under the Equal Protection Clause. Accordingly, Plaintiff's discrimination claim is reviewed under the rational basis standard. This finding is consistent with numerous other courts that have considered allegations of discrimination by transgender individuals.") But cf. Glenn v. Brumby, 663 F.3d 1312, 1317 (11th Cir. 2011) ("[D]iscrimination against a transgender individual because of her gender-nonconformity is sex discrimination, whether it's described as being on the basis of sex or gender.").

203 Silverman, supra note 199, at 348.

204 Kurzweil, supra note 200, at 208. See also e.g., Dani Heffernan, Colorado Trans Woman Denied Free Breast Cancer Screening by StateRun Program, GLAAD (Oct. 16, 2013), http://www.glaad.org/ blog/colorado-trans-woman-denied-free-breast-cancer-screening-staterun-program. [http://perma.cc/DZ3U-2JXP]. See also supra notes 95126 and accompanying text.

205 See Jamie D. Weinand \& Joshua D. Safer, Hormone Therapy in Transgender Adults is Safe with Provider Supervision; A Review of 
Finally, transgender people may receive greater access to care that is specific to the needs of their gender than do women. Insofar as gender confirming surgery is a medical need unique to transgender persons, and elective abortion is a medical need unique to women, the increasing availability of the former under Medicare and Medicaid stands in contrast to the reduced access to care that women experience under the Hyde Amendment.

In these four ways, transgender people are similarly situated to those traditionally gendered yet have reduced access to care by the realities of the operation of law. Importantly, for these issues and as a normative matter, transgender persons should benefit from efforts to remedy other gender-based disparities in healthcare access.

\section{REMEDIATING DISPARITIES IN ACCESS TO CARE THROUGH HEALTH AS A (NONEXISTENT) RIGHT}

The previous section explored the results of various laws and judicial decisions that impact access to health care, noting substantial gender-based disparities result from the agglomerated systems that seek to increase access and instances of judicial unwillingness to give weightier consideration to the access issue. In this section, this paper explains how current efforts to promote equitable access to health care by all genders demonstrate that a public policy of prioritizing health in decision-making by courts and states is appropriate. It does this by first acknowledging that although a constitutional right to health would be a clear mandate that favored health, such a right does not exist in the United States. But by juxtaposing the concept of a right to health with the somewhat disjointed efforts that have been undertaken to increase access to care, it becomes clearer that a judicially cognizable health-favoring policy can be viable.

Hormone Therapy Sequelae for Transgender Individuals, 2 J. CLINICAL \& TRANSLATIONAL ENDOCRINOLOGY 55 (2015) (providing an overview of current knowledge in transgender medicine as it relates to the safety of hormone therapy for transgender adults and noting that a severe limitation in the field is the lack of large-cohort studies to study the longterm effects of hormone therapy). 


\section{A. The International Formulation of a Right to Health and Access to Care}

If the United States has not comprehensively created a right to health-and perhaps, as explained below, cannot without foundational changes to the healthcare system as it is currently delivered and financed - then we must look to the international community to understand what such a formulation would look like and, moreover, how it defines access to care for similarly situated patients of different genders. ${ }^{206}$

As a preliminary matter, "the denial of health care has often been understood as essentially interfering with the 'right to health," from an international perspective."207 This is evident in both the Universal Declaration on Human Rights (UDHR), which provides the foundation for international human rights, ${ }^{208}$ and the International Covenant on Economic, Social and Cultural Rights (ICESCR), which articulates the most important statement of health as a human right. 209

The UDHR makes only one reference to health, declaring that "[e]veryone has the right to a standard of living adequate for [] health and well-being ... including food, clothing, housing and medical care and necessary social services, and the right to security in the event of ... sickness, [and]

206 See generally Eleanor D. Kinney, The International Human Right to Health: What Does This Mean for Our Nation and World?, 34 IND. L. REV. 1457 (2001) (arguing that international law has concrete implications for domestic policy-making regarding health).

207 Report of the Special Rapporteur on Torture and Other Cruel, Inhuman or Degrading Treatment or Punishment, Rep. of the Special Rapporteur on Torture and Other Cruel, Inhuman or Degrading Treatment or Punishment, I 11, U.N. Doc. A/HRC/22/53, Feb. 1, 2013.) (by Juan E. Méndez) [hereinafter Special Rapporteur on Torture], available at http://www.ohchr.org/Documents/HRBodies/HRCouncil/ RegularSession/Session22/A.HRC.22.53_English.pdf [http://perma.cc/ RK59-YLJJ]. Cf. Manjari Mahajan, The Right to Health as the Right to Treatment: Shifting Conceptions of Public Health, 79 Soc. RES. 819 (December (2012) (arguing that the right to health is unnecessarily indistinguishable from a right to health care in the international community).

208 Kinney, supra note 206, at 1459.

209 Id. 
disability . . . "210 The ICESCR is similar is in mandating that everyone have "the enjoyment of the highest attainable standard of physical and mental health." 211 The ICESCR further requires that four steps be taken to achieve "full realization" of the right, including by (1) reducing infant mortality and childhood morbidity; (2) improving living and work environments; (3) addressing all diseases, regardless of etiology; and (4) "assur[ing] to all medical service and medical attention in the event of sickness." 212 As with the UDHR, the ICESCR contains an acknowledgement of the impact of SDOH and couples it with an express statement that access to care is a component of the right to health.

Complementary for what it contributes to the remediation of gender-based health disparities, the Convention on the Elimination of All Forms of Discrimination Against Women (CEDAW) "devotes major attention to a most vital concern of women, namely their reproductive rights." 213 CEDAW references access to health care no fewer than six times and particular seeks "a basis of equality of men and women." 214 This goal of equalization is consistent with customary international health law, including as expressed by WHO. It is also in much the same vein as U.S. federal efforts that seek equity of men and women's access to health.

Gender-based disparities in access to health care have begun to inform other forms of international human rights law also. For instance, 2013, the U.N. Special Rapporteur sought to complement efforts to combat "violence against women by, inter alia, examining gender-specific forms of

210 Universal Declaration of Human Rights, G.A. Res. 217A (III), art. 25.1, U.N. Doc. A/810 at 71 (1948), available at http://www.un.org/ en/documents/udhr/ [https://perma.cc/C66U-NT5D].

211 International Covenant on Economic, Social and Cultural Rights, art. 12, Dec. 16, 1966, S. Treaty Doc. No. 95-19, 6 I.L.M. 360 (1967), 993 U.N.T.S. 3, (1976), available at http://www.ohchr.org/Documents/ ProfessionalInterest/cescr.pdf [https://perma.cc/N2PZ-KWNR].

212 Id.

213 Convention on the Elimination of All Forms of Discrimination Against Women, Dec. 18, 1979, 1249 U.N.T.S. 13, available at http:// www.un.org/womenwatch/daw/cedaw/text/econvention.htm\#part1 [https://perma.cc/K3SM-HC7P].

214 Id. at art. 1. 
torture" in the healthcare setting. ${ }^{215}$ Remarkably, on the list of practices found tantamount to torture is the "denial of legally available health services such as abortion and postabortion care."216 That report also addresses access to care by those who are transgender, most notably around forced medical procedures designed to rectify gender nonconformity; it concludes that section by noting that both formal and informal mechanisms of discrimination by governments and healthcare providers interfere with access to care. ${ }^{217}$

It is unsurprising that requirements of medically unnecessary surgery that castrate physical functioning would be considered torture, but even describing the inability to access otherwise lawful care as torture is consistent with an international sense of a right to health as a fundamental human right. Additionally, the plain language of the conventions noted above demonstrate that the right to health may be understood as consisting predominantly of a right to health care. However, U.S. courts have failed to recognize the international right to health, finding it "insufficiently definite" to constitute a normative rule of law. ${ }^{218}$

Regardless, in order for the international right to health to be adapted to fit U.S. customs, it must be broad enough as to encompass the negative "right to be let alone" that provides the foundation of U.S. jurisprudence underlying roughly half of individual healthcare access cases. ${ }^{219}$ This is important because were U.S. courts to recognize a broad right

215 Spécial Rapporteur on Torture, supra note 207, ๆ 45.

216 Id. ๆ 46.

217 Id. ๆ $76-79$.

218 E.g., Sarei v. Rio Tinto, 650 F.Supp.2d 1004 (C.D. Cal. 2009) (holding that an assertion to a right to health in an environmental pollution action fails because it is based on a norm that has not achieved the status of a matter of universal concern), vacated on other grounds, 133 S.Ct. 1995 (2013). Accord Flores v. S. Peru Copper Corp., 414 F.3d 233, 254 (2nd Cir. 2003) ("As an initial matter, we hold that the asserted 'right to life' and 'right to health' are insufficiently definite to constitute rules of customary international law."). See also Kinney, supra note 206, at 1471 (noting that implementation and enforcement of the right to health is difficult where it is predicated on customary international law).

219 For a treatise on the two legal mechanisms through which individual access to care is funneled, including public health and privacy, see generally B. Jesse Hill, The Constitutional Right to Make Medical Treatment Decisions: A Tale of Two Doctrines, 86 TEX. L. REV. 277 (2007). 
to health under domestic law, case law suggests that it might be founded on less-than-solid notions of autonomy.220 However, a significant challenge would exist in the United States in adapting a negative privacy-based right to health to make it a positive right to access to health care without a fundamental shift in law and policy. Thus this paper next considers the existence of positive rights of access to care in the United States.

\section{B. A Right to Health or Health Care Does Not Exist in the United States}

American scholars have for years argued that health is akin to other human rights. ${ }^{221}$ The concept has even been tied specifically to equalizing disparities in women's health and health care. ${ }^{222}$ Yet one might note that healthcare "seems to play second fiddle to other civil rights issues." 223

220 Id. See also FERNANDEZ LYNCH, supra note 188, at 37-42 (discussing the hypothetical right to care of a patient versus a physician's right to refuse to provide that care and describing the legal system as, from the patient perspective, a recognition of a "freedom from" rather than a "freedom to").

221 See, e.g., Kinney, supra note 206, at 1471 ("The human right to health is just a moral right after all."); Aart Hendriks, The Close Connection Between Classical Rights and the Right to Health, with Special Reference to the Right to Sexual and Reproductive Health, 18 MED. \& L. 225, 226 (1999) (arguing that "[realization] of this right depends necessarily on the protection afforded to certain classical human rights"). But see Richard Lamm, The Case Against Making Healthcare a Right, 25 HUM. RTS. 8, 9 (1998) ("It is problematic to consider healthcare as a 'right.' . . Rights are an ineffective way of determining who or what is covered"). Cf. Emanuel, supra note 12, at 104-107 (arguing that the most efficient distribution of resources would be through a framework for delineating specific medical services—and only those services-as rights). See generally JoHn TOBIn, THE Right TO HEALTH IN INTERNATIONAL LAW (2012) (providing a historical evaluation of the international right to health and seeking to develop a methodology that is implementable in the United States as with other human rights).

222 See Hilary Hammell, Is the Right to Health a Necessary Precondition for Gender Equality?, 35 N.Y.U. Rev. L. \& Soc. Change 131, 172 (2011) ("In the absence of a right to health, women in the United States face numerous barriers that prevent them from realizing their highest attainable standard of health.").

223 Silverman, supra note 199, at 347. 
Regardless, these discussions largely occurred before PPACA altered the health care schema in the United States, suggesting that revisiting the matter is timely. The timing is important because, as Erin C. Fuse Brown, for example, argues, PPACA can be understood as having created a "new right to health care for the uninsured."224 Fuse Brown concluded that the newly established right "will be ephemeral or hollow-a quasi-superstatute rather than a durable superstatute," ${ }^{225}$ which is logical if PPACA is viewed as "health insurance reform, not health care reform." 226 But neither formulation, nor the health-as-human-right discourse, addresses population-wide gender-based disparities in access to health care that result from a tradition of minimizing health in law and policy.

Although this minimization of health may result from a lack of a right to health, in part because such a right is frequently understood as encompassing a right to access needed health care, it is a steadfast status quo. Consider Fuse Brown's summary of the bleak landscape for the creation of such a doctrine:

[T] he U.S. Constitution provides neither a textual nor structural basis for such a right. ... Despite the limitations of a conceptual dichotomy between positive rights (e.g., entitlements to social goods) or negative rights (e.g., liberties or freedom from interference), this distinction is a useful description of the federal constitutional posture toward a right to health. . . . Nevertheless, the Court has not recognized a generally applicable positive right to health care, and it seems unlikely ever to do so. ${ }^{227}$

224 Erin C. Fuse Brown, Developing a Durable Right to Health Care, 14 MinN. J.L. SCI. \& TECH. 439, 444 (2013).

225 Id. at 490.

226 Alicia Ely Yamin, The Right To Health: Assessing How Far The Discourse Has Evolved Internationally and Within the United States, 104 AM. SoC'Y INT'L L. Proc. 14, 15 (2010).

227 Fuse Brown, supra note 224, at 455. Accord Rebecca E. Zietlow, Democratic Constitutionalism and the Affordable Care Act, 72 OHIO ST. L.J. 1367, 1382 (2011) ("The U.S. Constitution does not guarantee a right to health care. The U.S. Supreme Court rejected such a right, and held expressly that the government has no obligation to pay the medical expenses of indigents."). 
If this formulation is correct-and this paper assumes it is-then an alternative mechanism must be described if we are to look to law to remedy gender-based disparities in access to care. Any such framework need not recreate the wheel, however, and so this paper now turns to the established limited rights to health or health care that promote access in the United States.

\section{Legislated Limited Rights of Access to Specific Care in the United States}

Statutory rights are those that are grounded not in the Constitution, but rather in a statute. Similar are durable rights, or those that are accepted as fundamental legal norms but do not necessarily have a constitutional foundation. Both are more likely to suffer from ephemerality, as suggested above with regard to PPACA, due to the relative difficulty in entrenching them. In addition, there tend to be a plethora of mechanisms for challenging statutes.

Still, there are several instances of access to health care that have become nearly as embedded in the cultural expectation as a constitutional right. Only two relate to treatment for specific medical conditions for all adults as well as all children: hemodialysis for end-stage renal disease (ESRD) 228 and palliative care for amyotrophic lateral sclerosis (ALS), more colloquially known as Lou Gehrig's disease. 229 Both conditions trigger near-automatic coverage that is not by itself gender-dependent, though men are more likely than women to suffer from the two conditions and thus to need the coverage. ${ }^{230}$ Nonetheless, the history of access to

228 Social Security Amendments of 1972, Pub. L. No. 92-603, § 299I, 86 Stat. 1329, 1463 (codified at 42 U.S.C. $\$ 426-1$ ).

229 Consolidated Appropriations Act of 2001, Pub. L. No. 106-554, § 115, 114 Stat. 2763, A-474 (codified at 42 U.S.C. § 426(h)).

230 See Ctrs. For Disease Control \& Prevention, National Chronic Kidney DisEase FACT SheET, 2014, 1 (2014), available at http://www.cdc.gov/diabetes/pubs/pdf/kidney_factsheet.pdf

[http://perma.cc/MX5N-JAUK] ("Men with [chronic kidney disease] are $50 \%$ more likely than women to have kidney failure."); Who Gets ALS?, ALS ASS'N (Apr. 2015) ("ALS is $20 \%$ more common in men than in women."), http://www.alsa.org/about-als/who-gets-als.html/ [http:// perma.cc/4LGM-QNVS]. 
dialysis in particular is instructive in any discussion of the role of law in enabling access to health care and, especially, in the lack of a right to health care. ${ }^{231}$

As the first effort undertaken by Congress designed to increase access to treatment for a particular diagnosis, ${ }^{232}$ dialysis coverage expressly sought to remedy a disparity in access to care-that is, the lacuna between the wealthy and everyone else. ${ }^{233}$ Yet the design of the coverage in 1972 is one that, then and now, slightly favors men. This is because dialysis treatment is available only to those who are insured by definition of Title II of the Social Security Act, or the dependents thereof. ${ }^{234}$ As suggested supra, men are likely to achieve Title II-insured status of their own accord because, traditionally, men worked outside the home in greater numbers. However, when combined with the Social Security Administration's (SSA) treatment of a diagnosis of end-stage renal disease as an automatically disabling condition, coverage becomes effectively universal; Medicaid, which defines eligibility in accordance with the SSA, can then cover dialysis where Medicare does not even in the absence of the schema of expanded eligibility discussed above. ${ }^{235}$

But, as was asked by members of the Senate Finance Committee, "[w] hy favor this treatment ... over the long-term treatment of cancer," for example?236 Because it seems disingenuous to accept that end-stage renal disease represented "the one situation . . . where the only thing separating individuals from life and death was money," it is

231 E.g., EMANUEL, supra note 12, at 100-101 ("In the view of many, the development of the dialysis program typifies the more general 'crisis' in American medical care."); Richard A. Rettig, Origins of the Medicare Kidney Disease Entitlement: The Social Security Amendments of 1972, in BiomediCAL Politics 176, 203 (Kathi E. Hanna ed.,1991) (“The kidney disease entitlement remains a focus for debate about the relative benefits and burdens of medical technology.").

232 Rettig, supra note 231, at 177.

233 Carl W. Gottschalk, Commentary, in Biomedical Politics 209, 209-10 (Kathi E. Hanna ed., 1991).

23442 U.S.C. $\S 426-1$ (a) (2015).

235 Soc. SECURITY ADMIN., POMS DI 45001.001, End-Stage Renal Disease (ESRD) Entitlement Provisions (2013) available at http://policy.ssa.gov/poms.nsf/lnx/0445001001/ [http://perma.cc/9YHQF8JV].

236 Rettig, supra note 231, at 191. 
noteworthy that creation of a statutory right in this particular chronic disease was likely more a test of the viability of a national catastrophic health insurance program. ${ }^{237}$ Nonetheless, in the words of one of the original bill's constructionists, a physician, "[t]he equity issue was agonizing." 238

Forty years later, the dialysis coverage debate has not made materialize a system of catastrophic health insurance. Another then-senator had predicted why: "[W]e are picking out one particular sector of the whole health care problem, and because it is dramatic, we are trying to push it ahead of everything else. We can only handle so much." 239 Insofar as the right to health may be conflated with the right to health care, it is clear the practical limitations of finite social and fiscal resources make impossible a statutory right to medical treatment for all conditions in the same manner that hemodialysis is available for end-stage renal disease. Indeed, Medicare, which is not the only payer, contributed nearly $\$ 29$ billion in 2012 , or over $5 \%$ of its budget, to the care of the $1 \%$ of patients with end-stage renal disease. ${ }^{240}$

Dissimilarly, then, are smatterings of other statutory regimes that have in common only a foundational wealthbased inequity that could no longer be stomached. Addressed infra were disparities that result from some of these healthrelated schemas, such as coverage by the HIM, Medicaid, and Medicare, but others create more specific rights.

For instance, the Emergency Medical Treatment and Active Labor Act (EMTALA) created access to a minimum of stabilizing medical treatment where that treatment mitigates a life-threatening condition, but no more. ${ }^{241}$ Ostensibly grown out of the same concern for unnecessary suffering by the non-wealthy that informed coverage of

237 Id. at 191-92.

238 Id. at 210.

239 EMANUEL, supra note 12 , at 100 (quoting Senator Wallace Bennett).

240 U.S. RENAl Data System, 2014 AnNual Data REPorT Volume 2: END-STAGE RENAL DisEASE IN THE UNITED STATES 184 (2014), available at http://www.usrds.org/2014/download/v2_esrd_full_14.zip/ [http:// perma.cc/K2QW-MN8J].

24142 U.S.C. $§ 1395 d d(2011)$. 
dialysis, EMTALA forestalled the somewhat perverse tendency of some physicians to provide emergency care only if payment was guaranteed. Because low-income mothers-tobe were a particularly vulnerable population of patients likely to be "dumped," the act defines active labor as an emergency; the statuses of all other conditions are left to the judgment of the treating provider. ${ }^{242}$ The legislative determination that imminent childbirth constituted an emergency arguably conflicted with the medical understanding of labor, ${ }^{243}$ but it is consistent with other disparate legal treatment of pregnancy. Furthermore, as noted supra, women are greater users of Emergency Departments, suggesting that men's access to emergency care is not equally benefited. ${ }^{244}$

Other areas of law also create specific rights to health and health care. For example, concerns for health have been used to justify entitlements to habitable housing 245 and an unpolluted environment. ${ }^{246}$ Occupational regulations limit poor working conditions ${ }^{247}$ and intolerably low wages ${ }^{248}$ due, inter alia, to their negative influence on health. Public health

242 Id. $§ 1395$ dd (b).

243 Even post-EMTALA, judicial remedy was necessary to ensure access to emergency care by laboring women. For example, in Burditt v. U.S. Dep't of Health \& Human Servs., 934 F.2d 1362 (5th Cir. 1991), the plaintiff was denied stabilizing care and was instead transferred to a hospital 170 miles away. She gave birth in the ambulance. More recent medicalization of pregnancy might have resulted in different treatment even in the absence of EMTALA.

244 See supra text accompanying note 109.

${ }^{245}$ E.g., Conn. Gen. Stat. Ann. § 47a-7(a)(2) (West 2015) ("A landlord shall ... make all repairs and do whatever is necessary to put and keep the premises in [a] fit and habitable condition.").

246 E.g., Clean Water Act, Pub., L. No. 95-217, 91 State (1977) (codified at 33 U.S.C. § 1251) ("[I]t is the national goal that the discharge of pollutants into the navigable waters be eliminated . . .."). Id. § 1251(a)(1).

${ }^{247}$ E.g., Occupational Safety and Health Act, Pub. L. No. 91-596, § 2, 84 Stat. 1590 (1970 (codified at 29 U.S.C. § 651) (The "purpose and policy [is] to assure so far as possible every working man and woman in the Nation safe and healthful working conditions ....").

248 E.g., Fair Labor Standards Act, 29 U.S.C. § 202 (finding by Congress of "the existence . . of labor conditions detrimental to the maintenance of the minimum standard of living necessary for health ... ."). 
law even mandates health through provisos requiring inoculation against certain diseases ${ }^{249}$ and fluoridation of drinking water. ${ }^{250}$

In all of the above examples, the judiciary has found that the health benefit to the vulnerable masses, without regard for gender, supersedes contrary individual concerns. Although the physician may not get paid for the service provided, the emergent patient's treatment is superior to any takings claim or right to (not) contract. ${ }^{251}$ The landlord who would decline to maintain his properties, yet finds a willing tenant, loses as against that tenant whose health or physical safety is at risk. ${ }^{252}$ The corporation that may legitimately need to create and thus dump pollutants to produce a product cannot endanger nearby residents or ecosystems. ${ }^{253}$ The employer's financial security is less important than the employee's physical workspace ${ }^{254}$ and minimum wages. ${ }^{255}$ Conversely, there exists a right not to contract a communicable disease ${ }^{256}$ nor to have bad teeth. ${ }^{257}$

These varied examples show that there is a pervasive tendency in law to value individual access to health and even to health care. Such a robust history of health-favoring legislation and supportive judicial decision-making suggests that indeed, we as a nation intend to promote the health of all as a policy goal.

${ }^{249}$ E.g., Va. Code Ann. § 32.1-46(E) (West 2014) (requiring mandatory vaccinations "[f] or the purpose of protecting the public health by ensuring that each child receives age-appropriate immunizations ...").

${ }^{250}$ E.g., Colo. Rev. Stat. Ann § 25-215.5-102(1)(i) (West 2013) ("Water fluoridation is one of the most researched and cost-effective oral health interventions available ....").

${ }^{251}$ Burditt v. U.S. Dep't of Health \& Human Servs., 934 F.2d 1362, 1376 (5th Cir. 1991).

252 Kenyon v. Regan, 826 P.2d 140, 142 (Utah App. 1992).

253 U.S. v. Hooker Chem. \& Plastics (The Love Canal Case), 680 F.Supp. 546, 556 (W.D.N.Y. 1993).

${ }^{254}$ Miller v. Fed. Mine Safety \& Health Review Comm'n, 687 F.2d 194, 195 (1982).

255 W. Coast Hotel Co. v. Parrish, 300 U.S. 379, 394 (1937).

256 Jacobson v. Mass., 197 U.S. 11, 26 (1905).

257 Minn. Bd. of Health v. Brainerd, 241 N.W.2d 624 (1976). 


\section{The Melting Pot Federal Policy on Gender-Based Health Disparities}

Similarly suggestive are variations in executive efforts to remedy disparities in access to health care. Federally, there are six offices charged with supporting improvements specifically in women's health. These officers are contained in the National Institutes of Health (NIH), the Department of Health and Human Services (HHS), the Centers for Disease Control (CDC), the Food and Drug Administration (FDA), the Health Resources and Services Administration (HRSA), and the Agency for Healthcare Research and Quality (ARHQ). Four of the six offices were established within a four-year period in the early 1990's. ${ }^{258}$ Despite fifteen years of legislative efforts, ${ }^{259}$ all but the NIH's Office

258 Office of Research on Women's Health, NAT'L. Inst. OF HEALTH (Dec. 4, 2015) http://orwh.od.nih.gov/about/index.asp [http://perma.cc/ R462-E3YS] (giving 1990 as the date of establishment); Vision, Mission, History, DeP'T OF HEALTH \& HuMAN SeRvs. (Oct. 7, 2010), http://www.womenshealth.gov/about-us/mission-history-goals/ index.html [http://perma.cc/V7HM-A756] (1991); About CDC Office of Women's Health, Ctrs. FOR DiseAse CONTROL \& PREvention http://www.cdc.gov/women/about/index.htm [http://perma.cc/C9BZQ6FG] (last updated Jan. 20, 2015) (established in 1994); About Office of Women's Health, FOOD \& DRUG ADMIN. (Dec. 2, 2014), http:// www.fda.gov/AboutFDA/CentersOffices/OC/OfficeofWomensHealth/defa ult.htm [http://perma.cc/37JK-FBSA] (1994).

259 Women's Health Office Act of 1994, H.R. 3874, 103rd Cong. (1994); Women's Health Office Act of 1995, H.R. 1736, 104th Cong. (1995); Women's Health Office Act of 1995, S. 427, 104th Cong. (1995); Women's Health Office Act of 1997, H.R. 920, 105th Cong. (1997); Women's Health Office Act of 1997, S. 91, 105th Cong. (1997); Women's Health Office Act of 2000, H.R. 4483, 106th Cong. (2000); Women's Health Office Act of 2000, S. 2675, 106th Cong. (2001); Women's Health Office Act of 2002, H.R. 1784, 107th Cong. (2001); Women's Health Office Act of 2002, S. 946, 107th Cong. (2001); Women's Health Office Act of 2003, S. 1304, 108th Cong. (2005); Women's Health Office Act of 2004, H.R. 4354, 108th Cong. (2004); Women's Health Office Act of 2005 H.R. 949, 109th Cong. (2005); Women's Health Office Act of 2005 S. 569, 109th Cong. (2005); Women's Health Office Act of 2007, H.R. 1072, 110th Cong. (2007); Women's Health Office Act of 2007, S. 612, 110th Cong. (2007); Women's Health Office Act of 2009, H.R. 3242, 111th Cong. (2009) 
of Research on Women's Health were formally codified with the enactment of PPACA in 2010.260

The focus of each office might be thought of as an express extension to women-and often other demographic groups identified as experiencing significant disparities - of the umbrella agency's health-related priorities. The NIH office seeks to ensure that clinical research includes women and minorities, and that research on women's health and sex differences is expanded. ${ }^{261}$ The HHS Office on Women's Health helps women and girls "achieve the best possible health" through policy, education, and model programs, a three-part mission that reflects HHS's broader goals as the top department on all matters related to health. ${ }^{262}$ Similarly, the CDC's Office of Women's Health focuses on disease prevention and wellness for women and girls. 263

In contrast, there is no federal office dedicated solely to men's health. Congress has contemplated mandating such an office thirteen times this century, but these bills have not passed even one house. ${ }^{264}$ Instead, men's health is treated as a component of women's health: The CDC website on men's

260 PPACA $§ 2509$ (e) (codified at 42 U.S.C. 299c (2010) (AHRQ Office of Women's Health and Gender-Based Research); PPACA § 2509(f) (codified at 42 U.S.C. $\S 914$ (2010)) (HRSA Office of Women's Health); PPACA $\S 2509$ (g) (codified at 21 U.S.C. 399b (2010) (FDA Office of Women's Health); PPACA § 3509(a) (codified at 42 U.S.C. § 237a) (2010)) (HHS Office on Women's Health); PPACA § 3509(b) (codified at 42 U.S.C. $\S 242 \mathrm{~s}$ (2010)) (CDC Office of Women's Health). The NIH Office of Research on Women's Health was codified in the NIH Revitalization Act of 1993, Pub. L. No. 103-43.

261 Office of Research on Women's Health, supra note 258.

262 Vision, Mission, History, supra note 258.

263 About CDC Office of Women's Health, supra note 258.

264 Men's Health Act of 2000, H.R. 4653, 106th Cong. (2000); Men's Health Act of 2000, S. 2925, 106th Cong. (2000); Men's Health Act of 2001, H.R. 632, 107th Cong. (2001); Men's Health Act of 2002, S. 2616, 107th Cong. (2002); Men's Health Act of 2003, H.R. 1734, 108th Cong. (2003); Men's Health Act of 2003, S. 1028, 108th Cong. (2003); Men's Health Act of 2005, H.R. 457, 109th Cong. (2005); Men's Health Act of 2005, S. 228, 109th Cong. (2005); Men's Health Act of 2006, H.R. 5624, 109th Cong. (2006); Men's Health Act of 2007, H.R. 1440, 110th Cong. (2007); Men's Health Act of 2007, S. 640, 110th Cong. (2007); Office of Men's Health Act of 2007, H.R. 789, 110th Cong. (2007); Men and Families Health Care Act of 2009, H.R. 2115, 111th Cong. (2009). 
health, for instance, cites its Office of Women's Health as the source of its content. ${ }^{265}$ The HHS site uses the same header for its men's health page as for the women's health page, which, in the span of a few inches, references "women's health" four times. ${ }^{266}$ Though one might question the equity of this prioritization, at least one court has decided that there is no equality issue presented for want of any injury. 267

Despite studies suggesting that gender minorities are "disproportionately affected by adverse health outcomes compared to cisgender (i.e., non-gender minority) people,"268 federal policy does not prioritize health issues for those who consider themselves gendered in non-traditional fashion. In fact, of the aforementioned six federal offices dedicated to women's health, none lists the health of trans- or othergendered persons as a priority.

One other questionable consistency exists: as in the international context, women's health is often defined in terms of equity with men. Such formulation suggests that the collective goal is not truly to see that women achieve the highest state of healthy possible, but merely to no longer allow women to be left behind by the medical arts and sciences. As an equality matter, it is perhaps the best that law can do. However, as a matter of true equity and in accordance with the principles that underlie human rights and even population health, it should be understood as insufficient to seek to merely equalize access to health care.

265 Men's Health, Ctrs. FOR Disease Control \& Prevention, http://www.cdc.gov/men/ [http://perma.cc/FA6T-KP83] (last updated Nov. $4,2015)$.

266 Men's Health, DeP'T OF HEALTH \& HUMAN SERVs. http://www.womenshealth.gov/mens-health/ [http://perma.cc/32VY8A5X] (last updated Jan. 10, 2011).

267 Baldwin v. Sebelius, NO. 10CV1033 DMS (WMC), 2010 WL 3418436, at *1, *4 (S.D.Cal. Aug. 27, 2010).

268 Sari L. Reisner et al., Monitoring the Health of Transgender and Other Gender Minority Populations: Validity of Natal Sex and Gender Identity Survey Items in a U.S. National Cohort of Young Adults, 14 BMC Pub. HEalth 1224, 1224 (2014) (citing eight studies), available at http://www.biomedcentral.com/content/pdf/1471-2458-14-1224.pdf [http://perma.cc/WY9K-29BP]. See also supra text accompanying notes 199-205. 


\section{Shifting Public Policy In the ERA of PPACA ERA AND HEALTH-IN-ALL-POLICIES}

\section{A. The Judiciary and Legislative Support for Prioritizing Health as a Public Policy}

There is little doubt that a multitude of reasons can be given as to why we as a nation have not chosen to recognize a constitutional right to health. Moreover, there is little likelihood of a move toward recognizing health or health care as a right in the near future. Not only does the debate on the insurance reforms in PPACA suggest that health or health care as a right is politically untenable, ${ }^{269}$ but also the reality of social resources are such that there must be limits to public sponsorship of medical care. Therefore, in this subsection this paper explores how emphasizing the equity of access to health care would tend to rectify the disparities. It does this by substituting, in the areas of disparity laid out supra, a public policy that puts a thumb on the scale in favor of health. Such a policy contrasts with the current model of balancing that serves merely to reinforce socio-legal gender biases outside of health care. To be clear, the goal is expressly not "Cadillac" access to care for all, nor even mere adequate access for every conceivable infirmity. After all, "public policy ought to maximize a nation's health, not healthcare."270 Instead, then, the proposal is a specific and positive valuation of health that does not unnecessarily catalyze gender-based disparities, as does the status quo. As noted in the first section, this formulation is consistent with the conception of a health-related disparity as unnecessary, avoidable, unfair, and unjust.

\footnotetext{
269 E.g., Michael McAuliff, House Passes 56th Anti-Obamacare Measure, Huffington Post (Feb. 4, 2015, 12:59 AM), http://www.huffingtonpost.com/2015/02/03/repeal-

obamacare_n_6607080.html [http://perma.cc/8J56-6SM8] (describing the fifty-sixth vote by the House of Representatives against all or some of PPACA since 2011). But see Erin Merson, 3 Republicans Say No as House Again Votes Obamacare Repeal, Politico (Feb. 3, 2015, 8:09 PM), [http://perma.cc/M94P-3VH6] (noting that the February 2015 vote is the first time any Republicans have ever voted against total repeal).

270 Lamm, supra note 221, at 10.
} 
Politically, such focus is more than tenable for the judicial branch. Though the number of people who dislike but are medically buoyed by PPACA is a startling commentary on the contemporary constituency, ${ }^{271}$ and the judicial branch is less subject to political backlash than the legislature. This is not to suggest that public opinion should influence public policy -in fact, the two are unrelated except insofar as the public votes for its representatives and on state constitutional changes. ${ }^{272}$ Nor is this a call for much-derided "judicial activism," but rather a shift as a matter of public policy in order to be accordant with the actions of the legislative and executive branches. ${ }^{273}$

It is a doctrinally sound shift also. Although the U.S. Supreme Court has not iterated a precise definition, "public policy" has been defined in the academic literature as "a policy the objective of which is the common good; it is a policy which its maker believes will serve the people well." 274 It has also been described as "the very essence of law":

271 For example, polls have shown that while public opinion of PPACA has been middling, Americans overwhelmingly support the provisions within it. See Patricia Zengerle, Most Americans Oppose Health Law But Like Provisions, REUTERS (June 24, 2012, 1:13 AM), http://www.reuters.com/article/us-usa-campaign-healthcareidUSBRE85N01M20120625 [http://perma.cc/K7PJ-7T4W] (citing a Reuters/Ipsos poll); Mollyann BRODIE ET AL., KAISER HEALth TRACKING POLL: MARCH 2013 (describing monthly public opinion research on opinions of specific provisions and comparing those to poor awareness that PPACA is the source), available at https:// kaiserfamilyfoundation.files.wordpress.com/2013/03/8425-t1.pdf [http:// perma.cc/5WVE-Q7B2]. Similarly telling is the "viral" nature of a story of an opponent of PPACA who soon found himself needing to access care yet was financially unable to do so. See Ann Doss Helms, Who Should Save Sight of SC Man Who Can't Afford Surgery?, CHARLOTTE OBSERVER (May 12, 2015 2:00 AM), http:// www.charlotteobserver.com/ news/business/health-care/health-care-challenge-blog/ article20696283.html [https://perma.cc/Z99Q-4NYZ].

272 Richard H.W. Maloy, Public Policy-Who Should Make it in America's Oligarchy?, 1998 DET. C.L. REV. 1143, 1155 (1998).

273 Erich Vieth \& James P. Lemonds, Whence Public Policy?52 J. Mo. B. 239, 243 (1996) (calling judicial legislating "the most serious and recurrent objection to public policy" yet noting that it is "a legitimate tool of [Judges'] trade").

274 Maloy, supra note 272, at 1145, 1154. 
The very considerations which judges most rarely mention, and always with an apology, are the secret root from which the law draws all the juices of life. I mean, of course, considerations of what is expedient for the community concerned. Every important principle which is developed by litigation is in fact and at bottom the result of more or less definitely understood views of public policy; most generally, to be sure, under our practice and traditions, the unconscious result of instinctive preferences and inarticulate convictions, but nonetheless traceable to views of public policy in the last analysis. ${ }^{275}$

Because public policy cannot and should not exist in a judicial vacuum, devoid of any explanation for its occasion, ${ }^{276}$ it is worth noting that specifically in regard to PPACA, the Court has noted the individual mandate of healthcare insurance as "Congress's solution to these problems" of financial access to care. ${ }^{277}$ Thus, to weigh the congressional determination that remedying disparities in access to care is a worthy goal would require the courts merely to follow what seems an express greater good in the public's interest. This is the essence of good public policy.

Despite the lack of express definition by the Court, it has been relatively consistent in assuming that public policy is to be made by the people through the legislature. ${ }^{278}$ Thus insofar as Congress has made a clear statement of public policy, the courts should follow suit absent Constitutional invalidity. ${ }^{279}$ Given that statutory rights often form the basis of judicial policy concerns, it would be most consistent with the values set forth by Congress for jurisprudential policy to

275 Vieth \& Lemonds, supra note 273, at 239 (summarizing and then quoting Justice Oliver Wendell Holmes).

276 Id. at $245-46$.

277 Nat'l Fed. Of Indep. Bus. v. Sebelius, 132 S.Ct. 2566, 2585 (2012).

278 Maloy, supra note 272, at 1144-45. See also Nat'l Fed. Of Indep. Bus., 132 S.Ct. at 2579 ("[W]e possess neither the expertise nor the prerogative to make policy judgments. Those decisions are entrusted to our Nation's elected leaders, who can be thrown out of office if the people disagree with them. It is not our job to protect the people from the consequences of their political choices.").

279 Id. at $1168-69$. 
more accurately reflect the increased financial access to care established by PPACA. ${ }^{280}$

Also supporting judicial recognition of a public policy shift is the relatively new Health-in-All-Policies (HiAP) approach of population health. "At its core, Health in All Policies represents an approach to addressing the social determinants of health, which are the key drivers of health outcomes and health inequities." 281 In short, HiAP supplements population health by emphasizing the influence on health of policies that are not traditionally associated with public health. ${ }^{282}$ Indeed, "HiAP provides a means to identify and avoid the unintended impacts of public policy that can be detrimental to the health of populations or subgroups of the population." 283 An express goal is remedying health inequities. ${ }^{284}$ Because, as delineated above, SDOH also influence access to care, the increasing pervasiveness of HiAP should have implications for judicial interpretation also, and particularly as public policy.

For example, it is known that "today nearly all aspects of the built environment are shaped by law,"285 suggesting that law has a significant role to play in ensuring that access to care is not defeated by poor civil design. For example,

280 Other scholars have also viewed PPACA as changing the public policy of health care in various contexts. See, e.g., Fuse Brown, supra note 224 (arguing that PPACA created a durable right to health care); Karen Oehme \& Nat Stern, The Case for Mandatory Training on Screening for Domestic Violence in the Wake of the Affordable Care Act, 17 U. PA. J. L. \& Soc. CHANGE 1, 1, 13 (2014) (calling PPACA a "historic opportunity" to address domestic violence as a public health and criminal matter); Sara Rosenbaum, Law and the Public's Health, 126 PUB. HEALTH REP. 130, 130 (2011) (terming PPACA a "watershed" in public health policy), available at http://www.ncbi.nlm.nih.gov/pmc/ articles/ PMC3001814/pdf/phr126000130a.pdf [http://perma.cc/FD9X-SYCU].

281 Linda Rudolph et Al., AM. Pub. Health Ass'N, Health in All Policies: A GUide FOR STATE AND LOCAL GOVERNMENTS 8 (2013), available at https://www.apha.org/ /media/files/pdf/fact\%20sheets/ health_inall_policies_guide_169pages.ashx [https://perma.cc/4BJPFM96].

282 For various definitions of Health in All Policies, see id. at 138.

283 WHO HIAP, supra note 30 , at 4.

284 Id. at 40; RUDOLPH ET AL., supra note 281, at 8.

285 Wendy Collins Perdue, Lesley A. Stone \& Lawrence O. Gostin, The Built Environment and Its Relationship to the Public's Health: The Legal Framework, 93 AM. J. PuB. HEALth 1390, 1390 (2003). 
Perdue, Stone, and Gostin note that urban areas where constituents are unable to advocate politically are the first places that hospitals and other healthcare clinics close. ${ }^{286}$ Not only does such a situation reduce access to those types of medical facilities, but the providers that are left experience greater strain in trying to deliver care, further decreasing access to care. ${ }^{287}$ By prioritizing health, the physical environment is built in a way that facilitates access to care. The HiAP approach would ensure that everyone from city councilmen making zoning determinations to civil engineers designing the city structure would consider the impact on access to care in their decision-making. HiAP works as congruently with mitigation of the other SDOH.

\section{B. Access to Care Redux}

So how would health as a public policy priority effect equitable access to care by all people regardless of gender?

Justice Oliver Wendell Holmes observed that "[t]he very meaning of public policy is the interest of others than the parties and that interest is not to be at the mercy of the defendant alone."288 Presumably the Justice would not make it at the mercy of the plaintiff either. Through health as a public policy priority, the judiciary might better balance doctrines that interfere with access to care. In the Hobby Lobby case, instead of truly considering only whether costfree contraceptive coverage by the business's insurer constituted an undue burden on religion, the Court would have to weigh the impact on health and access to care. This analysis would look more like balancing of religious freedom and other governmental initiatives that the Court has undertaken. For instance, theoretically applying the same federal statute at issue in Hobby Lobby, the Religious Freedom Restoration Act, to the matter of taxation, the Court in Hobby Lobby maintained that the burden to the tax system would be too great. ${ }^{289}$ Indeed, the majority predicted "chaos." 290

286 Id. at 1391.

287 Id.

288 Beasley v. Tex. \& Pac. Ry. Co., 191 U.S. 492, 498 (1903).

289 Burwell v. Hobby Lobby Stores, Inc., 134 S. Ct. 2751, 2784 (2014).

290 Id. 
Although the Court does not acknowledge it, there is a great distinction in the value it places on the benefit of taxes to operations government versus the difficulty of excluding religious objectors, and the benefit of access to prophylactic care to female employees versus the difficulty of excluding the objectors. That is, the "fundamental point" of whether there is a "less restrictive alternative" 291 obscures the counter-claims and renders them of no import. The dissent likens the inadequate weight given by the Court to the access to care claims to a right to swing one's arms, which, as the apologue goes, ends where another's nose begins. ${ }^{292}$

Thus, by applying to health those same concerns of the impracticality of a two-tiered system of taxes, the Court would have to weigh the impairment on access to care presented by the arguments of Hobby Lobby. Rather than dismissively stating that female employees still have access because the general public can absorb their cost-share, ${ }^{293}$ as the majority did, the Court would balance, as suggested by the dissent, that there is significant impact on access to care. ${ }^{294}$ This is particularly true where precedent may allow a future court to further diminish the importance of the health populace where, for instance, the effect is somewhat more than the "precisely zero" amount that the Hobby Lobby Court found. ${ }^{295}$ Although having a direct impact on the access to care by women, as it was at issue in the case, this suggested collectivist public policy understanding of health would improve access to care by men and women both and on an individual and population level. ${ }^{296}$

Accordant is King and associated cases, wherein the plaintiffs contended that tax credits and subsidies should not be available in exchanges set up by or in partnership with the federal government. Those Courts would be free to disregard the petitioner's claims based not only on legislative history,

291 Id.

292 Id. at 2791 (Ginsburg, J., dissenting).

293 Id. at 2760.

294 Id.

295 Id. at 2760.

296 See Mahajan, supra note 207, at 834 ("A renewed focus on the collectivity in public health might lead to more sustainable and equitable arrangements that appreciate state's responsibilities to the larger public good, which are indispensable to ensuring health to the individual."). 
which they collectively found unhelpful,297 but also on the presumption that Congress intended to increase access to care nationwide and not at the whim of ideologically opposed state governors. ${ }^{298}$ Given the attempts to wholesale modify the entire private healthcare insurance market, it is an assumption grounded in logic that efficacious change could not be accomplished by increasing insurance availability for only select citizens. ${ }^{299}$ It is also an assumption grounded in a health-prioritizing perspective. That the Kings may thusly genuinely suffer harm because of this proposed public policy is consistent with public health law at large because that doctrine values health-and access to health care-over individual objection.

In some ways the circuit courts in these cases recognized such a value. Both the Pruitt and Halbig courts supposed that they were "ensuring that policy is made by elected, politically accountable representatives, not by appointed lifetenured judges" by holding in favor of the plaintiffs. 300 Though implicitly tautological in nature due to the courts' notice of both the "high stakes" 301 of the case and PPACA's "lofty goals" 302 while holding in contrary fashion to both, the recognition of the importance of public policy in these decisions suggests that there may be a judicial want for a mechanism for favoring health. The court in Halbig noted,

297 Compare Halbig, 758 F.3d at 407-12 ("[T]he legislative record provides little indication one way or the other of congressional intent"), and King, 759 F.3d at 372 ("[N]othing in the legislative history of the Act provides compelling support for either side's position"), with Pruitt, 758 F.3d at $1088 \mathrm{nn} \cdot 15-16$ (describing why it found the legislative history irrelevant).

298 The Fourth Circuit effectively came to this conclusion, catalyzing the King petition for certiorari, when it held that Chevron deference meant accepting the plausible determinations of the Internal Revenue Service. See King, 759 F.3d at 368-69.

299 See, e.g., Halbig, 758 F.3d at 406 n.10 (discussing increased access under PPACA of the Children's Health Insurance Program, which uses the same language at issue in the case before the court, and observing that "we recognize the oddity of requiring some states and not others to take this step ...").

300 Pruitt, 51 F.Supp.3d at 1092; Halbig, 758 F.3d at 412.

301 Pruitt at 1091.

302 Halbig, 758 F.3d at 412. 
for instance, that it "reach[ed] [its] conclusion, frankly, with reluctance." 303

That reluctance was shared by the Supreme Court, but only because it found the text ambiguous and thus sought to "produce[] a substantive effect that is compatible with the rest of the law."304 Although the Court subscribed to the belief that "Congress passed the Affordable Care Act to improve health insurance markets, not to destroy them[,]" 305 it does not expressly consider that the health of the populace, insofar as access to care is a determinant of health, should be a sufficient catalyst in holding against the plaintiffs.

It seems, then, that there is a trend of courts unwilling to protect access to care by individuals - and often along gender lines-unless there exists an economic harm to the masses. Such harm, of course, would belie the definition of health and misunderstand access to health care. Thus because "the very process of litigation around socioeconomic rights tends to produce a relative sidelining of the public good," 306 and because, as described above, there is no right to health, there should be broad judicial notice that the discrete issues highlighted by PPACA-related lawsuits are not necessarily actions designed to benefit the masses, though the petitioners may so believe. But "[j]udges must be careful that, by the use of objectivist abstractions, they don't overly distance themselves from the human beings their decisions will effect [sic]." 307 If the courts will not concern themselves with access to care by the population at large, who will?

One need only consider the Baldwin case mentioned supra to find an example of the clear inequity that results from failure to appreciate the value of health and health care amidst other doctrinal concerns. In that case, the court found that the temporal and financial resources provided to women's health did not create inequality for men, but not as a matter of health and certainly not in terms of the gender

303 Id.

304 King v. Burwell, 135 S.Ct. 2480, 2484 (2015) (quoting United Sav. Ass' $n$ of Tex. v. Timbers of Inwood Forest Assocs., 484 U.S. 365, 371 (1988)).

305 Id. at 2496.

306 Mahajan, supra note 207, at 829.

307 Vieth \& Lemonds, supra note 273, at 246. 
health disparity that was alleged.308 Rather, the court responded to the plaintiff's claimed harm dismissively with only a conclusory statement that there was insufficient demonstration of any injury. ${ }^{309}$

By putting Baldwin's claim in the context in which it was made- that is, relative to the PPACA provisions that finally codified multiple offices of women's health, all of which expressly seek to improve various forms of access to care by women-one must consider that perhaps men's health is undervalued in this law and policy. Through a public policy lens that emphasizes health, this is clearly a gender-based disparity that is unnecessary, avoidable, unfair, and unjust. After all, the offices were created and funded because research will follow dollars, suggesting that there may be decreased economic incentive to prioritize men's health. And though Congress and the agencies themselves must-and should-mean to improve women's health, they surely do not intend to do so at the expense of men. Disparity cannot be remedied through complete diversion; rather, it is through the affirmative act of prioritizing parity that inequality is resolved.

Yet health as a public policy priority does not require that access always and necessarily be favored. In National Federation of Independent Businesses, for example, which challenged, inter alia, the mandatory Medicaid expansion, nullification might still have resulted. After all, the Court's opinion effectively rested on antifederalist public policy that precludes the coercion of the states by the federal government. 310 Because the states' entire pool of Medicaid dollars were at risk, ${ }^{311}$ finding the expansion unduly coercive was likely.

Nonetheless, through increased prioritization of health the Court at least would have had additional support in noting the legislative goals in mandating-and providing

308 Baldwin v. Sebelius, NO. 10CV1033 DMS (WMC), 2010 WL 3418436, at *4 (S.D.Cal. Aug. 27, 2010).

309 Id.

310 Nat'l Fed. Of Indep. Bus. v. Sebelius, 132 S.Ct. 2566, 2601-07 (2012) (“[T]he financial 'inducement' Congress has chosen is much more than 'relatively mild encouragement'-it is a gun to the head."). Id. at 2604.

311 Id. 
long-term funding for-the expansion. Consider the plethora of instances of PPACA that assume the Medicaid expansion, including the nonexistence of credits and subsides for those under $100 \% \mathrm{FPL}$ and the relatively low value of the financial assistance for those covered under the expansion. Had Congress not contemplated a blanket increase in access to care for the indigent, particularly as opposed to the option to forego insurance and pay a penalty for those of less modest income, the body would not have created the dual tiers.

The Court also could then have considered the impact of no expansion on the healthcare system at large. Because uncompensated care costs average $\$ 50$ billion per year nationally, it would not correct the issue of access to care if whole states were left without coverage for their poor. ${ }^{312}$ Compounding the effect is that, as explicated above, the poor are more likely to lack both employment-based and private insurance, and they are also more likely to be medically indigent, suffering greater mortality and morbidity than do those with higher incomes. So while the Medicaid expansion may have still been deemed too coercive to withstand constitutional muster, under the public policy prioritization of health and access to care proposed herein, the Court may have at least considered the effect on health and access to care of making optional the expansion.

Greater gender parity in access to care would result because the Medicaid expansion gave to indigent, childless men an option for coverage that does not otherwise exist. Traditionally, however, although private healthcare insurance is broadly obtained in similar numbers by men and women, but in lesser numbers by the transgender, men have had the greatest independent insurance coverage. This disparity is due to a recent national history that ties healthcare insurance to employment during working years, along with the subsequent availability of Medicare in retirement only for those with a sufficient pattern of work. As noted above, healthcare insurance coverage and financial barriers are widely accepted measures of access to health care.

To the extent that PPACA sought to remedy disparities in financial access to care, a public policy favoring health would

312 DeLEIRE ET AL., supra note 145, at 3. 
tend to make enforcement of individual provisions easier, in part by facilitating a joint effort. For instance, the failure of insurers to implement PPACA cost-share preventive provisions implicates state governments, who are tasked with enforcing insurance laws. While legal education of citizens on rights to challenge insurance coverage denials would surely decrease the number of abuses, state department of insurance regulators are well-positioned to create systemic changes by prioritizing the issue. Although law already encourages this enforcement, the federal government could reinforce its commitment and its law through limited grants that might be made available to entice states to prioritize this issue. 313

With regard to state legislatures, at a minimum and as a matter of federalism, they may not conflict with federal precedent once a public policy on a matter has been established. ${ }^{314}$ Examples of the efficacy of health and access to care as a public policy priority might be found in the Illinois legislature's current attempt to create a more patientand health-friendly balance between the genuine religious objections of Catholic providers and the patients who rely on them for health care. ${ }^{315}$ That bill would require that healthcare providers inform patients of their options rather than merely refusing to provide the requested care, in the process under-informing the patient. ${ }^{316}$ The text of the bill contains an express statement of impetus: it is "the public policy of the State of Illinois to ensure that patients receive timely access to information and medically appropriate care." 317 Disallowing further expansion of conscience clauses as a matter of public policy increases access to care across the board, particularly for those in rural areas, and especially for women to the extent that their access is disproportionately

313 See Oehme \& Stern, supra note 280, at 17-20 (discussing PPACA as creating an "opportunity for cooperative federalism").

314 See Maloy, supra note 272, at 1169 (noting that courts may "strike down a state's public policy [if] there is a conflict with federal public policy").

315 Health Care Right of Conscience Act, S.B. 1564, 99th Leg., Reg. Sess. (Ill. 2015).

316 Id. $\S 6.1$.

317 Id. $\S 2$. 
affected by a refusal to provide medical treatment or prescriptions drugs.

\section{CONCLUSION}

It has been observed that as a nation we "limit healthcare in one of the cruelest ways that any nation can do so-by simply leaving people out of the system."318 Although limitations in access to health care may be inevitable, it should be unacceptable that law and policy have embedded gender-based disparities into the access equation. These gender-based disparities exist through codified schema generally designed to facilitate access to care, both as an accidental and deliberate by-product of philosophies and doctrines that are granted greater importance than access to care. With regard to the failure of law to increase access to care, remediable areas include those that create disparities in access through a deprioritization of health. Making health a public policy priority is appropriate given that PPACA changed the healthcare landscape; this paper is not the first to suggest that we are now in an era of even more deliberate efforts to erase disparities in access to care. The judiciary and states should follow suit and recognize the emphasis that the other federal branches have placed on health in order to avoid disparities that are unnecessary, avoidable, unfair, and unjust. 